\title{
Synthesis and characterization of thiosemicarbazonato
}

\section{molybdenum(VI) complexes and their in vitro antitumor activity}

Višnja Vrdoljak, ${ }^{a}$ Ivica Đilović, ${ }^{a}$ Mirta Rubčić, ${ }^{a}$ Sandra Kraljević Pavelić, ${ }^{c}$ Marijeta Kralj, ${ }^{\mathrm{c}}$ Dubravka Matković-Čalogović, ${ }^{\mathrm{a}}$ Ivo Piantanida, ${ }^{\mathrm{b} * *}$ Predrag Novak, ${ }^{\mathrm{a}}$ Andrea Rožman, ${ }^{\mathrm{a}, \mathrm{b}}$ Marina Cindrić ${ }^{\mathrm{a} *}$

${ }^{\text {a }}$ Faculty of Science, Chemistry Department, Horvatovac $102^{\mathrm{a}}$, 10000 Zagreb, Croatia

${ }^{\mathrm{b}}$ Division of Organic Chemistry and Biochemistry, Ruđer Bošković Institute Zagreb, Croatia

${ }^{c}$ Division of Molecular Medicine, Ruđer Bošković Institute, Zagreb, Croatia

Authors for correspondence:

* Prof. Dr. M. Cindrić, tel: +385 1 4606351, Fax: : + 385-1-46 06341 e-mail address: marina@chem.pmf.hr

** Dr. Ivo Piantanida; tel: +385 14571 210; Fax: + 38514680 195, e-mail address: pianta@irb.hr 


\begin{abstract}
New dioxomolybdenum(VI) complexes were obtained by the reaction of $\left[\mathrm{MoO}_{2}(\mathrm{acac})_{2}\right]$ with thiosemicarbazone ligands derived from 3-thiosemicarbazide and 4-(diethylamino)salicylaldehyde $\left(\mathbf{H}_{2} \mathbf{L}^{\mathbf{1}}\right)$, 2-hydroxy-3-methoxybenzaldehyde $\left(\mathbf{H}_{2} \mathbf{L}^{\mathbf{2}}\right)$ or 2-hydroxy-1-naphthaldehyde $\left(\mathbf{H}_{\mathbf{2}} \mathbf{L}^{\mathbf{3}}\right)$. In all complexes thiosemicarbazonato ligands are coordinated to molybdenum as tridentate $O N S$-donors. Octahedral coordination of each molybdenum atom is completed by methanol molecule (in 1a-3a) or by oxygen atom of $\mathrm{Mo}=\mathrm{O}$ unit from the neighbouring molecule (in 1-3). All complexes were characterized by means of chemical analyses, IR spectroscopy, TG and NMR measurements. The molecular structures of the ligand $\mathbf{H}_{2} \mathbf{L}^{2}$ and complex $\left[\mathrm{MoO}_{2} \mathrm{~L}^{2}\left(\mathrm{CH}_{3} \mathrm{OH}\right)\right] \cdot \mathrm{CH}_{3} \mathrm{OH}(\mathbf{2 a})$ have been determined by single crystal X-ray crystallography. The characterisation of thiosemicarbazonato molybdenum(VI) complexes (1-4) as well as of the 4-phenylthisemicarbazonato molybdenum(VI) complexes (5-8) in aqueous medium revealed that upon dissolving complexes in water, most likely to some extent dissociation took place, although experimental data didn't allow exact quantification of dissociation. The antiproliferative effects of studied molybdenum(VI) complexes (1-8) on the human cell lines were identical to the activity of their corresponding ligands.
\end{abstract}

Keywords: thiosemicarbazone; molybdenum(VI) complexes; X-ray crystal structures; antiproliferative effects; tumour cell lines. 


\section{Introduction}

Since first study on thiosemicarbazones activity against Mycobacterium tuberculosis [1] many other biological activities of this type molecules have been described, for instance antitumoral, antifungal and antiviral $[2,3]$. Thiosemicarbazones, in their neutral or deprotonated form, behave as a ONS/NNS tridentate or tetradentate chelate towards metal ions essential for life. Important finding was that a $N N S$ thiosemicarbazone ligand system was a common feature of all compounds with carcinostatic potency. Some thiosemicarbazones, such as marboran or triapine, are already used in medical practice. Recent discovery of the antitumor effects of metal complexes and their potential use in cancer diseases have received increasing attention [4,5]. Metal complexes show an activity which, if compared with that of the corresponding ligands, is of the same order of magnitude and often larger [6].

Metal chelation is an important process useful to afford new chemical features to metal complexes in order to make them suitable for pharmacological applications. Many useful drugs contain metal-binding sites, which may alter the physiological profile of the free species. Some of them increase their activity by their ability to form chelates with specific metal ion. For example, cellular uptake of copper-chelated thiosemicarbazones is advanced over that of free ligand because of the enhanced lipophilicity of the metal-drug combination [7].

The transition element molybdenum (Mo) is of essential importance for nearly all biological systems as it is required by enzymes catalyzing diverse key reactions in the global carbon, sulphur and nitrogen metabolism. It occurs in a wide range of 
metalloenzymes in bacteria, fungi, algae, plants and animals where it forms part of the active sites of these enzymes. The active site includes the metal atom coordinated to one or two pyranopterin molecules and to a variable number of ligands such as oxygen, sulphur and selenium atoms [8,9]. Diverse class of molybdenum complexes were prepared, tested and developed for various pharmaceutical purposes, whereby their anticancer activities gained special attention. For example, tetrathiomolybdate (TM) is an anticopper drug under development for treating Wilson's disease. Its mechanism of action involves forming a tight tripartite complex in the blood with serum albumin and available copper. In addition, it has been shown that lowering copper levels with TM produces an antiangiogenic, anticancer effect, probably due to inhibition of many copper-dependent proangiogenic cytokines. Therefore, it has shown a promising role in suppressing tumor angiogenesis, retinal neovascularization, and pathologic inflammatory conditions $[10,11]$.

Additionally, polyoxometalates, negatively charged inorganic substances which contain early transitional metal ions and make a cluster with the surrounding oxygen atoms are a large class of inorganic compounds with great molecular diversity and significant potential applications in chemistry and medicine [12]. Yamase had reported that significant antitumoral effect of polyoxomolybdates, especially $\left[\mathrm{NH}_{3} \mathrm{Pr}^{\mathrm{i}}\right]_{6}\left[\mathrm{Mo}_{7} \mathrm{O}_{24}\right] \cdot 3 \mathrm{H}_{2} \mathrm{O}(\mathrm{PM}-8)$ was found against MX-1 murine mammary cancer cell line, Meth A sarcoma and MM46 adenocarcinoma [13]. Our group also showed that $\gamma$-octamolybdates containing aminoacids and peptides showed differential cellgrowth inhibition in a dose-dependent manner selectively on hepatocellular carcinoma cell line (HepG2) and breast cancer cell line (MCF-7) [14]. 
Furthermore, metallocene diacido complexes containing transition metals, such as titanium, vanadium, niobium, zirconium, and molybdenum, also exhibit variable antitumor activity for a wide spectrum of murine and human tumors with reduced toxicity when compared with cisplatin [15].

In our previous paper [16], we have reported synthesis and characterisation of several new thiosemicarbazone derivatives, as well as strong antiproliferative activity of these compounds against several human tumor cell lines. In a continuation of our work concerning the coordination chemistry $[17,18,19]$ and biological activity of thiosemicarbazones [16] we have prepared several new molybdenum(VI) complexes (1-3 and 1a-3a) (Scheme 1).

Scheme 1.

The complexes $\left[\mathrm{MoO}_{2} \mathrm{~L}\right]_{\mathrm{n}}(\mathbf{1 - 3}$, described in here-presented study and 4-8, known from our previous investigation $[17,18]$ ) were also tested for their antiproliferative ability against selected human tumor cell lines and compared to parent thiosemicabazone ligands. Here presented synthetic, structural and biological studies have been carried out in order to obtain information on structure-activity relationships for systems involving molybdenum(VI) ions.

\section{Experimental}

General remarks: The starting acetylacetonato complex $\left[\mathrm{MoO}_{2}(\mathrm{acac})_{2}\right]$ and thiosemicarbazones $\left(\mathbf{H L}^{\mathbf{1}} \mathbf{- H L} \mathbf{L}^{\mathbf{3}}\right)$ were prepared as described in the literature $[20,16]$. 
The complexes $\left[\mathrm{MoO}_{2} \mathrm{~L}\right]_{\mathrm{n}}(\mathbf{4 - 8})$ were synthesized according to the published procedure $[17,18]$ All aldehydes and thiosemicarbazide were of reagent grade and used as purchased. Methanol was dried using magnesium shavings and iodine and then distilled. Acetonitrile and dichloromethane were dried over $\mathrm{P}_{2} \mathrm{O}_{5}$ and distilled. $\mathrm{C}, \mathrm{H}$ and $\mathrm{N}$ analyses were provided by the Analytical Services Laboratory of Ruđer Bošković Institute, Zagreb. Molybdenum was determined according to the method described in literature [21].

IR spectra were recorded as $\mathrm{KBr}$ pellets using Perkin-Elmer Fourier-Transform Spectrum RX1 Spectrophotometer in the region $4500-450 \mathrm{~cm}^{-1}$. Thermogravimetric analyses were measured on a Mettler TG 50 thermobalance using aluminum crucibles under oxygen atmosphere with a heating rate of $5{ }^{\circ} \mathrm{C} \min ^{-1}$. For all experiments the temperature ranged from 25 to $600{ }^{\circ} \mathrm{C}$. The results were developed by applying the Mettler STAR ${ }^{\mathrm{e}}$ 6,1. programme. Thermal analysis data are given in Table 1.

\subsection{Synthesis of complexes}

\subsubsection{Synthesis of $\left[\mathrm{MoO}_{2} \mathrm{~L}\right]_{n}(1-3)$}

Molybdenum(VI) complexes were obtained by reacting an acetonitrile $(20 \mathrm{~mL})$ suspension of $\left[\mathrm{MoO}_{2}(\mathrm{acac})_{2}\right](0.46 \mathrm{mmol})$ and stehiometric amount of the appropriate ligand $\mathbf{H}_{2} \mathbf{L}\left(\mathbf{H}_{2} \mathbf{L}^{1}, \mathbf{H}_{2} \mathbf{L}^{2}\right.$ or $\left.\mathbf{H}_{2} \mathbf{L}^{3}\right)$. The reaction mixture was slowly refluxed for $7 \mathrm{~h}$ and the complexes as dark red $(0.15 \mathrm{~g}, \mathbf{1})$, orange $(0.11 \mathrm{~g}, 2)$ and yellowish-brown $(0.12 \mathrm{~g}, 3)$ solids were precipitated. The obtained products were collected by filtration, washed well with acetonitrile and dried in vacuum. 
(1) $\left[\mathrm{MoO}_{2}\left(\mathrm{C}_{12} \mathrm{H}_{16} \mathrm{~N}_{4} \mathrm{OS}\right)\right]_{\mathrm{n}}$ : Yield. 83\%. Anal. Calcd. for: $\mathrm{C}_{12} \mathrm{H}_{16} \mathrm{MoN}_{4} \mathrm{O}_{3} \mathrm{~S} ; \mathrm{C}, 36.74$; H, 4.11; N, 14.28; S, 8.17; Mo, 24.46\%; Found: C, 36.79; H, 3.98; N, 14.29; S, 8.34; Mo, 24.52\%. IR $\left(\mathrm{cm}^{-1}\right)$ in $\mathrm{KBr}: 1633(\mathrm{~s}), 1610(\mathrm{vs}), 1572(\mathrm{vs}), 1507(\mathrm{vs}), 1410(\mathrm{~m})$, 1352(s), 1248(s), 1138(s), 933(s), 846(vs).

(2) $\left[\mathrm{MoO}_{2}\left(\mathrm{C}_{9} \mathrm{H}_{9} \mathrm{~N}_{3} \mathrm{O}_{2} \mathrm{~S}\right)\right]_{\mathrm{n}}$ : Yield. 68\%. Anal. Calcd. for: $\mathrm{C}_{9} \mathrm{H}_{9} \mathrm{MoN}_{3} \mathrm{O}_{4} \mathrm{~S} ; \mathrm{C}, 30.78 ; \mathrm{H}$, 2.58; N, 11.97; S, 9.13; Mo, 27.32\%; Found: C, 30.83; H, 2.70; N, 11.59; S, 9.35; Mo, 27.00\%. IR $\left(\mathrm{cm}^{-1}\right)$ in $\mathrm{KBr}: 1624(\mathrm{~s}), 1567(\mathrm{~m}), 1538(\mathrm{~s}), 1529(\mathrm{~s}), 1328(\mathrm{~m}), 1266(\mathrm{~s})$, 935(s), 911(s) 806(vs), 755(s).

(3) $\left[\mathrm{MoO}_{2}\left(\mathrm{C}_{12} \mathrm{H}_{9} \mathrm{~N}_{3} \mathrm{OS}\right)\right]_{\mathrm{n}}$ : Yield. 82\%. Anal. Calcd. for: $\mathrm{C}_{12} \mathrm{H}_{9} \mathrm{MoN}_{3} \mathrm{O}_{3} \mathrm{~S} ; \mathrm{C}, 38.83 ; \mathrm{H}$, 2.44; N, 11.32; S, 8.64; Mo, 25.84\%; Found: C, 38.25; H, 2.58; N, 11.24; S, 8.73; Mo, 23.38\%. IR $\left(\mathrm{cm}^{-1}\right)$ in $\mathrm{KBr}: 1619(\mathrm{~m}), 1594(\mathrm{~m}), 1557(\mathrm{~s}), 1512(\mathrm{~m}), 1331(\mathrm{~m}), 1281(\mathrm{~m})$, 931(s), 916(m) 819(vs), 772(m).

\subsubsection{Synthesis of $\left[\mathrm{MoO}_{2} \mathrm{~L}\left(\mathrm{CH}_{3} \mathrm{OH}\right)\right](1 \mathrm{a}-3 \mathrm{a})$}

Complexes 1-3 $(0.26 \mathrm{mmol})$ were dissolved in dry methanol and the solutions were warmed up for $4 \mathrm{~h}$ ( $2 \mathrm{~h}$ for $\mathbf{3 a})$. The solution was evaporated to one third of its volume under reduced pressure and left several days at room temperature.

The obtained crystalline products $(0.1 \mathrm{~g}$, $1 \mathbf{a}$ dark red; $0.07 \mathrm{~g}, \mathbf{2 a}$ orange, $0.07 \mathrm{~g}, \mathbf{3 a}$ dark red) were collected by filtration, washed well with cold tetrachloromethane and dried in vacuum.

(1a) $\left[\mathrm{MoO}_{2}\left(\mathrm{C}_{12} \mathrm{H}_{16} \mathrm{~N}_{4} \mathrm{OS}\right)\left(\mathrm{CH}_{3} \mathrm{OH}\right)\right]$ : Yield. 55\%. Anal.Calcd.for: $\mathrm{C}_{13} \mathrm{H}_{20} \mathrm{MoN}_{4} \mathrm{O}_{4} \mathrm{~S}$; C, 36.80; H, 4.75; N, 13.20; S, 7.56; Mo, 22.61\%; Found: C, 36.62; H, 4.25; N, 13.64; S, 
7.20; Mo, 23.00\%. IR ( $\left.\mathrm{cm}^{-1}\right)$ in $\mathrm{KBr}: 1633(\mathrm{~s}), 1610(\mathrm{vs}), 1573(\mathrm{vs}), 1509(\mathrm{vs}), 1352(\mathrm{~s})$, 1315(m), 1248(vs), 1138(s), 933(m).

(2a) $\left[\mathrm{MoO}_{2}\left(\mathrm{C}_{9} \mathrm{H}_{9} \mathrm{~N}_{3} \mathrm{O}_{2} \mathrm{~S}\right)\left(\mathrm{CH}_{3} \mathrm{OH}\right)\right]$ : Yield. $46 \%$. Anal.Calcd.for: $\mathrm{C}_{10} \mathrm{H}_{13} \mathrm{MoN}_{3} \mathrm{O}_{5} \mathrm{~S} ; \mathrm{C}$, 31.34; H, 3.42; N, 10.96; S, 8.37; Mo, 25.03\%; Found: C, 30.96; H, 3.07; N, 11.32; S, 8.59; Mo, 24.92\%. IR ( $\left.\mathrm{cm}^{-1}\right)$ in $\mathrm{KBr}: 1626(\mathrm{~s}), 1594(\mathrm{~m}), 1563(\mathrm{~m}), 1514(\mathrm{~s}), 1460(\mathrm{~s})$, 1337(m), 1263(vs), 932(s), 901(vs).

(3a) $\left[\mathrm{MoO}_{2}\left(\mathrm{C}_{12} \mathrm{H}_{9} \mathrm{~N}_{3} \mathrm{OS}\right)\left(\mathrm{CH}_{3} \mathrm{OH}\right)\right]$ : Yield. 38\%. Anal.Calcd.for: $\mathrm{C}_{13} \mathrm{H}_{13} \mathrm{MoN}_{3} \mathrm{O}_{4} \mathrm{~S}$; C, 38.72; H, 3.25; N, 10.42; S, 7.95; Mo, 23.79\%; Found: C, 38.54; H, 3.41; N, 10.47; S, 7.86; Mo, 23.52\%. IR ( $\left.\mathrm{cm}^{-1}\right)$ in $\mathrm{KBr}: 1616(\mathrm{~s}), 1593(\mathrm{~s}), 1578(\mathrm{w}), 1550(\mathrm{~s}), 1508(\mathrm{~m})$, 1332(m), 938(m), 891(s).

\subsection{X-ray crystallography}

Data collection was performed on Oxford Diffraction Xcalibur CCD diffractometer with graphite-monochromated Mo $K \alpha$ radiation at $293 \mathrm{~K}$, using $\omega$-scans at crystal to detector distance of $60 \mathrm{~mm}$. Details of data collection and crystal structure refinement are summarized in Table 2 .

The programs CrysAlis CCD and CrysAlis RED [22] were used for data collection, cell refinement and data reduction. The structure was solved by direct methods. Refinement procedure by full-matrix least squares methods based on $F^{2}$ values against all reflections included anisotropic displacement parameters for all non- $\mathrm{H}$ atoms. The positions of hydrogen atoms were determined on stereochemical grounds, each riding on their carrier atom. Calculations were performed with SHELXS97 [23] and SHELXL97 [24] (both operating under WinGX [25] program package). The molecular 
graphics were done with PLATON98 [26] and Mercury [27]. Selected bond distances and valence angles are listed in Table 3.

\subsection{NMR spectroscopy}

One- and two-dimensional $\left({ }^{1} \mathrm{H}, \mathrm{APT}, \mathrm{gCOSY}, \mathrm{gHSQC}\right.$ and gHMBC) NMR spectra were recorded at ambient temperature on the Avance DRX500 spectrometer using a 5 $\mathrm{mm}$ diameter inverse detection probe with $z$-gradient. The spectra were recorded in DMSO- $d_{6}$ with the sample concentration of $20 \mathrm{mg} \mathrm{mL}^{-1}$ and TMS as the internal standard. Typical spectral conditions for one-dimensional ${ }^{1} \mathrm{H}$ and ${ }^{13} \mathrm{C}$ (APT) spectra were as follows. The spectra were recorded using $64 \mathrm{~K}$ data points and spectral widths of $6200 \mathrm{~Hz}$ and $20000 \mathrm{~Hz}$ for proton and carbon (APT) experiments, respectively. Digital resolution was $0.10 \mathrm{~Hz}$ and $0.30 \mathrm{~Hz}$ per point, respectively. The number of scans was 8-16 for ${ }^{1} \mathrm{H}$ and 1000-3000 for APT spectra. 2D gradient selected COSY spectra were acquired with a sweep width of $6000 \mathrm{~Hz}$ in both dimensions into $2 \mathrm{~K}$ data points with 256 increments. Spectra were zero-filled in the $\mathrm{f} 1$ dimension to $1 \mathrm{~K}$ and processed using an unshifted sine bell window function. Digital resolution was $3.91 \mathrm{~Hz}$ per point in both dimensions. The gradient selected inverse ${ }^{1} \mathrm{H}^{-13} \mathrm{C}$ correlation experiments, gHSQC and gHMBC were recorded at $125.77 \mathrm{MHz}$ using the acquisition matrix of $1 \mathrm{~K} \times 256$ with 32 scans and processed with $2 \mathrm{~K}$ x $1 \mathrm{~K}$ transformed matrix. The sweep width was $7500 \mathrm{~Hz}$ in $\mathrm{f} 2$ dimension and $31500 \mathrm{~Hz}$ in $\mathrm{f} 1$ dimension for both experiments. Spectra were processed with a shifted sine bell window function and linear prediction. Digital resolution was $3.25 \mathrm{~Hz}$ per point and $30.70 \mathrm{~Hz}$ per point in $\mathrm{f} 2$ 
and $\mathrm{f} 1$, respectively. HMBC spectra were recorded using transfer delay for the evolution of long range $\mathrm{C}-\mathrm{H}$ couplings of $60 \mathrm{~ms}$.

\subsection{Spectrophotometric experiments}

The electronic absorption spectra were recorded on Varian Cary 100 Bio spectrometer, and fluorescence emission spectra were recorded on Varian Eclipse fluorimeter, in all cases using quartz cuvettes $(1 \mathrm{~cm})$. The measurements were performed in the aqueous buffer solution $\left(\mathrm{pH}=7.0\right.$; sodium cacodylate buffer, $\left.I=0.05 \mathrm{~mol} \mathrm{dm}^{-3}\right)$. Under the experimental conditions used the absorbance and fluorescence intensities of studied compounds were proportional to their concentrations. Titrations of $\mathbf{H}_{2} \mathbf{L}^{\mathbf{1}}-\mathbf{H}_{2} \mathbf{L}^{\mathbf{8}}$ with dioxobis(2,4-pentanedionato)molybdenum(VI), $\left[\mathrm{MoO}_{2}(\mathrm{acac})_{2}\right]$ were performed by adding aliquots of $\left[\mathrm{MoO}_{2}(\mathrm{acac})_{2}\right]$ into cuvette with aqueous solution of the corresponding $\mathbf{H}_{2} \mathbf{L}$ followed by measuring the spectrum. Binding constants $(\log K s)$ and complex stoichiometries were calculated by processing titration data (complete spectra) by Specfit program [28].

\subsection{Interactions with ct-DNA}

The calf thymus DNA (ct-DNA) was purchased from Aldrich, dissolved in the sodium cacodylate buffer, $I=0.05 \mathrm{~mol} \mathrm{dm}^{-3}, \mathrm{pH}=7.0$, additionally sonicated and filtered through a $0.45 \mu \mathrm{m}$ filter and the concentration of corresponding solution determined spectroscopically as the concentration of phosphates. Spectroscopic titrations were performed by adding portions of ct-DNA solution into the solution of the studied compound. Thermal melting curves for ct-DNA and its complexes with studied species 
were determined as previously described by following the absorption change at $260 \mathrm{~nm}$ as a function of temperature [16]. The absorbance of the ligand was subtracted from every curve, and the absorbance scale was normalized. Obtained $T_{\mathrm{m}}$ values are the midpoints of the transition curves, determined from the maximum of the first derivative or graphically by a tangent method. Given $\Delta T_{\mathrm{m}}$ values were calculated subtracting $T_{\mathrm{m}}$ of the free nucleic acid from $T_{\mathrm{m}}$ of complex. Every $\Delta T_{\mathrm{m}}$ value here reported was the average of at least two measurements, the error in $\Delta T_{\mathrm{m}}$ is $\pm 0.5^{\circ} \mathrm{C}$.

\subsection{Antiproliferative activity assay.}

The HeLa (cervical carcinoma), Hep-2 (laryngeal carcinoma), MCF-7 (breast carcinoma), SW620 (colon carcinoma), MiaPaCa-2 (pancreatic carcinoma) and Hep-2 (laringeal carcinoma) and WI 38 (normal diploid fibroblasts) cells (obtained from American Type Culture Collection (ATCC, Rockville, MD, USA) were cultured as monolayers and maintained in Dulbecco's modified Eagle's medium (DMEM) supplemented with $10 \%$ fetal bovine serum (FBS), $2 \mathrm{mM} \mathrm{L-glutamine,} 100 \mathrm{U} / \mathrm{ml}$ penicillin and $100 \mu \mathrm{g} / \mathrm{mL}$ streptomycin in a humidified atmosphere with $5 \% \mathrm{CO}_{2}$ at $37^{\circ} \mathrm{C}$. The growth inhibition activity was assessed as described previously, according to the slightly modified procedure of the National Cancer Institute, Developmental Therapeutics Program [16]. The cells were inoculated onto standard 96-well microtiter

plates on day 0 . The cell concentrations were adjusted according to the cell population doubling time (PDT): $1 \times 10^{4} / \mathrm{mL}$ for HeLa, Hep-2, MiaPaCa-2 and SW620 cell lines $(\mathrm{PDT}=20-24 \mathrm{~h}), 2 \times 10^{4} / \mathrm{mL}$ for MCF-7 cell line $(\mathrm{PDT}=33 \mathrm{~h})$ and $3 \times 10^{4} / \mathrm{mL}$ for WI $38(\mathrm{PDT}=47 \mathrm{~h})$. Test agents were then added in five dilutions $\left(10^{-8}\right.$ to $\left.5 \times 10^{-6} \mathrm{~mol} / \mathrm{l}\right)$ 
and incubated for a further 72 hours. Working dilutions were freshly prepared on the day of testing. After 72 hours of incubation, the cell growth rate was evaluated by performing the MTT assay, which detects dehydrogenase activity in viable cells. Each test was performed in quadruplicate in three individual experiments. The results are expressed as $\mathrm{IC}_{50}$, which is the concentration necessary for $50 \%$ of inhibition. The $\mathrm{IC}_{50}$ values for each compound are calculated from concentration-response curves using linear regression analysis by fitting the test concentrations that give PG values above and below the reference value (i.e. 50\%). If however, for a given cell line all of the tested concentrations produce PGs exceeding the respective reference level of effect (e.g. PG value of 50), then the highest tested concentration is assigned as the default value, which is preceded by a ">" sign. Each result is a mean value from three separate experiments.

\section{Results and discussion}

\section{1. Synthesis}

As a part of our studies on molybdenum(VI) complexes with oxygen, sulphur and/or nitrogen donor ligands new polynuclear $\left[\mathrm{MoO}_{2} \mathrm{~L}\right]_{\mathrm{n}} \quad(\mathbf{1 - 3})$ and mononuclear $\left[\mathrm{MoO}_{2} \mathrm{~L}\left(\mathrm{CH}_{3} \mathrm{OH}\right)\right]$ complexes (1a-3a) were isolated (Scheme 1). Polynuclear molybdenum(VI) complexes were obtained in the reaction of $\left[\mathrm{MoO}_{2}(\mathrm{acac})_{2}\right]$ and equimolar amount of the appropriate thiosemicarbazone ligands derived from 4-(diethylamino)salicylaldehyde $\left(\mathbf{H}_{2} \mathbf{L}^{\mathbf{1}}\right)$ hydroxy-3-methoxybenzaldehyde $\left(\mathbf{H}_{2} \mathbf{L}^{2}\right)$ or 2-hydroxy-1-naphthaldehyde $\left(\mathbf{H}_{2} \mathbf{L}^{3}\right)$ in acetonitrile. Compounds $\mathbf{1}, \mathbf{2}$ and $\mathbf{3}$ are dark red, orange or yellowish-brown powders, respectively and their polynuclear structure 
changes to monomeric in methanolic solution. The complexes 4-8 were prepared in a similar way, as already described in the literature $[17,18]$. The complexes of general formulae $\left[\mathrm{MoO}_{2} \mathrm{~L}\left(\mathrm{CH}_{3} \mathrm{OH}\right)\right]\left(\mathrm{L}=\mathbf{L}^{\mathbf{1}}, \mathbf{L}^{\mathbf{2}}\right.$ and $\left.\mathbf{L}^{\mathbf{3}}\right)$ were isolated from concentrated methanolic solutions.

Infrared spectra and thermal analyses: In the IR spectra of complexes $\left[\mathrm{MoO}_{2} \mathrm{~L}\right]_{\mathrm{n}}(\mathbf{1 - 3})$ the intense bands $775-846 \mathrm{~cm}^{-1}$ region and a single strong absorption band found in the $891-964 \mathrm{~cm}^{-1}$ region were assigned to the $\mathrm{Mo}=\mathrm{O} \cdots$ Mo bridging and terminal $\mathrm{Mo}=\mathrm{O}$ groups. The appearance of the $v_{\text {asym }}\left(\mathrm{MoO}_{2}\right)$ and $v_{\text {sym }}\left(\mathrm{MoO}_{2}\right)$ within the $926-938 \mathrm{~cm}^{-1}$ and $891-901 \mathrm{~cm}^{-1}$ regions, respectively and the absence of the band, in the $770-850$ $\mathrm{cm}^{-1}$ region, indicative of intermolecular metal $\cdots$ oxygen interaction is characteristic of the spectra of monomeric complexes $\left[\mathrm{MoO}_{2} \mathrm{~L}\left(\mathrm{CH}_{3} \mathrm{OH}\right)\right]$. The bands in the 1633-1514 $\mathrm{cm}^{-1}$ region were assigned to the stretching vibrations of $\mathrm{C}=\mathrm{N}$ and $\mathrm{C}-\mathrm{O}_{\text {phenolic }}$ thiosemicarbazone groups, respectively. These and all other frequencies founded in the IR spectra of complexes are in accordance to the literature data for the same type of complexes $[29,30]$.

According to the X-ray structure analysis complex $\mathbf{2 a}$ is solvated with one methanol molecule $\left[\mathrm{MoO}_{2} \mathrm{~L}^{2}\left(\mathrm{CH}_{3} \mathrm{OH}\right)\right] \cdot \mathrm{CH}_{3} \mathrm{OH}$. The crystals were loosing solvent at room temperature so that they were left in a desiccator up to constant weight and analyzed as unsolvated species $\left[\mathrm{MoO}_{2} \mathrm{~L}^{2}\left(\mathrm{CH}_{3} \mathrm{OH}\right)\right]$. Thermal analyses of all prepared $\left[\mathrm{MoO}_{2} \mathrm{~L}\left(\mathrm{CH}_{3} \mathrm{OH}\right)\right]$ complexes $(\mathbf{1 a - 3 a})$ revealed two main processes: loss of coordinated methanol molecule in first step and decomposition of complex on further heating. The solid residues were identified as $\mathrm{MoO}_{3}$. 


\section{TABLE 1}

\subsection{Molecular and crystal structures}

Selected bond distances and angles are given in Table 3. An ORTEP wiew of the $\mathbf{H}_{2} \mathbf{L}^{2}$ is shown in Fig. 1. The 2-hydroxy-3-methoxybenzaldehyde thiosemicarbazone molecule $\left(\mathbf{H}_{2} \mathbf{L}^{2}\right)$ exists in the keto (thione) tautomeric form [C-S amounts 1.697(3) $\AA$ ], with the trans configuration of the $\mathrm{S} 1$ atom with respect to the $\mathrm{N} 3$ and with $\mathrm{N} 1$ in the cis configuration with respect to the N3. Molecule is built of two planar moieties: aliphatic thiosemicarbazone part (defined by $\mathrm{C} 1, \mathrm{C} 2, \mathrm{~N} 1, \mathrm{~N} 2, \mathrm{~N} 3$ and S1 atoms with maximum deviation from mean plane of -0.031(2) $\AA$ for N3) and methoxyphenolic part (defined by remaining non-hydrogen atoms with maximum deviation from mean plane of $-0.013(4) \AA$ for C7). Dihedral angle between these two planes is $12.78^{\circ}$. This mild inclination mostly affects crystal packing because it brings molecules in good position for hydrogen bonding formation and saturation. The bond distances within thiosemicarbazone chain show $\pi$-electron delocalization. Although the 2-hydroxy-3methoxybenzaldehyde thiosemicarbazone is highly related to the other salycilaldehyde thiosemicarbazone derivatives [31], the intramolecular hydrogen bond between hydroxyl group and N3 atom is not observed. This can be due the presence of another hydrogen bond acceptor as suggested in some earlier papers.

\section{Figure 1.}


The crystal packing is characterized by hydrogen bonding interactions between the molecules. Fig. 2 depicts centrosymmetric $R_{2}^{2}(8)$ dimers which are held together by hydrogen bonds of $\mathrm{N} 2-\mathrm{H} 2 \mathrm{~N} \cdots \mathrm{S} 1^{\mathrm{i}}$ type $(i=1-x, 1-y,-z)$ forming layers which are parallel to the crystallographic (201) plane. Layers are interconnected with hydrogen bonds of $\mathrm{N} 1-\mathrm{H} 1 \mathrm{NA} \cdots \mathrm{O} 3^{\mathrm{ii}}(i i=1-x, y+1 / 2,1 / 2-z)$ and $\mathrm{O} 3-\mathrm{H} 3 \mathrm{O} \cdots \mathrm{S} 1^{\mathrm{iii}}(i i i=1-x$, $y-1 / 2,1 / 2-z)$ type.

\section{Figure 2.}

In the molecular structure of the compound $\left[\mathrm{MoO}_{2} \mathrm{~L}^{2}\left(\mathrm{CH}_{3} \mathrm{OH}\right)\right] \cdot \mathrm{CH}_{3} \mathrm{OH}(\mathbf{2 a})$, the molybdenum atom displays a slightly distorted octahedral coordination involving oxygen, sulphur and nitrogen atoms from an 2-hydroxy-3-methoxybenzaldehyde thiosemicarbazone acting as a tridentate ligand, two oxygen atoms from cis- $\left[\mathrm{MoO}_{2}\right]^{2+}$ unit and solvent molecule (Fig. 3, Table 3). Like in almost all cis-dioxo molybdenum coordination compounds, the central metal ion is not in the centre of the octahedron but is shifted towards terminal oxygen atoms by the same degree. The distance from the plane defined by S1, N3, O1 and O3 is $0.3624(4) \AA$. Because of the above mentioned fact, five and six-membered chelate rings are not planar which indicate non-planarity of the ligand in the complex $\left[\mathrm{MoO}_{2} \mathrm{~L}^{2}\left(\mathrm{CH}_{3} \mathrm{OH}\right)\right] \cdot \mathrm{CH}_{3} \mathrm{OH}(\mathbf{2 a})$

\section{Figure 3.}


In $\left[\mathrm{MoO}_{2} \mathrm{~L}^{2}\left(\mathrm{CH}_{3} \mathrm{OH}\right)\right] \cdot \mathrm{CH}_{3} \mathrm{OH}(\mathbf{2 a})$ complex $\mathrm{Mo}-\mathrm{O}$ distances of the $\left[\mathrm{MoO}_{2}\right]^{2+}$ units are mostly as expected, indicating that they are double bonds. In the regular octahedrons, angles between cis ligands are $90^{\circ}$. Observed $\mathrm{O}=\mathrm{Mo}=\mathrm{O}$ angle is significantly larger than regular one, indicating greater repulsion between oxygen atoms closely bounded to the central metal atom. Coordination of the molybdenum(VI) ion by the solvent molecule is weakened which is reflected in the lengthening of Mo-O5 distance (Table 3) in comparison with Mo-donor atom bond lengths found during survey of the Cambridge Structural Database [32]. This lengthening of Mo-O5 distance indicates trans influence of terminal oxo-oxygen atom bounded on molybdenum as described in literature [33]. The relative positions of the $\mathrm{N}$ and $\mathrm{S}$ atoms from thiosemicarbazone change upon complexation with molybdenum and vanadium, for example [34]. This event is accompanied with lengthening of $\mathrm{C} 1-\mathrm{S} 1, \mathrm{C} 1-\mathrm{N} 1, \mathrm{~N} 2-\mathrm{N} 3, \mathrm{C} 2-\mathrm{N} 3, \mathrm{C} 3-\mathrm{C} 4$ and shortening of $\mathrm{C} 1-\mathrm{N} 2, \mathrm{C} 2-\mathrm{C} 3, \mathrm{C} 4-\mathrm{O} 3$ bonds (in comparison with ligands free form) which is expected because some of mentioned atoms are now involved in chelatation. Crystal packing of $\left[\mathrm{MoO}_{2} \mathrm{~L}^{2}\left(\mathrm{CH}_{3} \mathrm{OH}\right)\right] \cdot \mathrm{CH}_{3} \mathrm{OH}$ (2a) complex (Fig. 4) is characterized with strong hydrogen bonding interactions of $\mathrm{N}-\mathrm{H} \cdots \mathrm{N}$ type $\left(R_{2}^{2}(8)\right)$ and the $\mathrm{N}-\mathrm{H} \cdots \mathrm{O}$ type $\left(D_{1}^{1}(3)\right)$. The terminal amino group has used its full potential for forming intermolecular interactions. The solvating methanol molecule is linked to the oxygen atom of $c i s-\left[\mathrm{MoO}_{2}\right]^{2+}$ unit by an $\mathrm{O}-\mathrm{H} \cdots \mathrm{O}$ hydrogen bond. Additionally, the crystal packing is stabilized by great variety of weaker intermolecular interactions of $\mathrm{C}-\mathrm{H} \cdots \mathrm{O}$ and $\mathrm{C}-\mathrm{H} \cdots \pi$ type.

\section{Figure 4.}




\section{TABLE 2,}

\section{TABLE 3}

\subsection{Study of molybdenum(VI) complexes in solution}

\subsubsection{NMR spectroscopy}

Although molybdenum(VI) complexes were well characterized in the solid state, their characterization in solution is necessary in order to evaluate the stability of studied complexes under biologically relevant conditions. However, poor solubility of molybdenum(VI) (1-3) complexes and related free ligands hampered NMR experiments in water; therefore spectra were recorded in DMSO- $d_{6}$. The proton and carbon chemical shifts (Table 4, Scheme 2) were assigned by using one $\left({ }^{1} \mathrm{H}\right.$ and APT) and twodimensional (COSY, HSQC and HMBC) NMR experiments. The ${ }^{1} \mathrm{H}$ and ${ }^{13} \mathrm{C}$ chemical shifts of the third interacting site, i.e. C-5 are all downfield and appreciable smaller (2-3 ppm).

\section{Scheme 2.}

\section{TABLE 4}

The ${ }^{1} \mathrm{H}$ and ${ }^{13} \mathrm{C}$ chemical shift values are similar to those previously reported for the related ligands and their $\mathrm{Mo}(\mathrm{VI})$ complexes $[17,18]$. A relatively broad $\mathrm{OH}$ resonance was observed for all ligands at approximately $10 \mathrm{ppm}$, reflecting intramolecular hydrogen bonding interactions in DMSO- $d_{6}$, which was consistent with the previous results. According to the chemical shifts, all ligands exist in the hydroxy-thione tautomeric form in DMSO- $d_{6}$ as found in the solid state. 
In the ${ }^{1} \mathrm{H}$ spectra of of compounds $\mathbf{1 - 3}$ signals belonging to phenolic $\mathrm{OH}$ and $\mathrm{NH}-2$ protons are absent which is due to formation of the complexes. As a consequence, the NH-4 protons experience an up-field shift of approximately $1 \mathrm{ppm}$. The carbon chemical shifts exhibit much larger changes, up to $10.64 \mathrm{ppm}$ as observed for $\mathrm{C}-1$ atom in $\mathbf{2}$ and 13.96 ppm for C-3 in 1. These effects are down-field for the former and upfield for the later site. The observed shielding and deshielding effects are a consequence of electron redistribution upon complexation. The total effect at C-3 is a superposition of a coordination-induced effect and the formation of an imine instead of a thiocarbonyl bond.

\subsubsection{Spectrophotometric properties of aqueous solutions of molybdenum(VI)} complexes 1-8 in comparison to corresponding free ligands $\mathbf{H}_{2} \mathbf{L}^{\mathbf{1}}-\mathbf{H}_{2} \mathbf{L}^{\mathbf{8}}$

We have chosen UV/Vis and fluorescence spectroscopy for further studies in aqueous solution since metal coordination usually has profound impact on the electronic properties of organic ligand. All studied complexes are poorly soluble in water, although significantly better than free ligands [16]. Therefore, for easier manipulation in further experiments, stock solutions of 1-8 complexes were prepared in DMSO at $c=5 \times 10^{-3}-1 \times 10^{-2} \mathrm{~mol} \mathrm{dm}{ }^{-3}$. For all experiments small aliquots of DMSO stock solutions were added into the aqueous medium to give homogeneous solutions with DMSO content of less than 5\%. The UV/Vis spectra of $\mathbf{1 - 8}$ complexes (Fig. 5) are linearly dependent on the concentration of compounds up to $1 \times 10^{-5} \mathrm{~mol} \mathrm{dm}^{-3}$, except for the complex 7, which precipitated at c $>8 \times 10^{-6} \mathrm{~mol} \mathrm{dm}^{-3}$. 


\section{Figure 5.}

\section{TABLE 5}

The UV/Vis spectra (Fig. 5, Table 5) of molybdenum complexes $\mathbf{1 - 8}$ resemble quite closely by shape to those of the corresponding ligands $\mathbf{H}_{2} \mathbf{L}^{\mathbf{1}}-\mathbf{H}_{2} \mathbf{L}^{\mathbf{8}}$ [16], differing only by values of molar extinction coefficients. However, temperature dependent changes of the UV/Vis spectra of 2-7 complexes and corresponding free ligands differed significantly (data not shown).

All studied complexes 1-8, as well as corresponding free ligands $\mathbf{H}_{2} \mathbf{L}^{\mathbf{1}}-\mathbf{H}_{2} \mathbf{L}^{\mathbf{8}}$, exhibit strong fluorescence emission (Fig. 6), linearly dependent on concentration up to $c=8 \times 10^{-6} \mathrm{~mol} \mathrm{dm}^{-3}$.

\section{Figure 6.}

Comparison of UV/Vis (Fig. 5) and fluorescence emission (Fig. 6) spectra of free ligands [16] and their molybdenum complexes dissolved in water revealed in most cases distinct differences, pointing that molybdenum complexes didn't completely dissociated into free ligands.

In addition, temperature dependent changes in the UV/Vis and fluorescence spectra of free ligands and related molybdenum(VI) complexes, were in most cases significantly different. 
Obtained results clearly indicate that most of Mo complexes upon dissolving in water do not completely dissociate into free ligand and $\mathrm{Mo}^{\mathrm{VI}} \mathrm{O}_{2}{ }^{2+}$ cation. However, only determination of stability constants of Mo(VI) complexes under biologically relevant conditions can give exact information about percentage of complex dissociation. For this reason we have performed UV/Vis and fluorimetric titrations of free ligands with dioxobis(2,4-pentanedionato)molybdenum(VI) $\left[\mathrm{MoO}_{2}(\mathrm{acac})_{2}\right]$ in aqueous medium.

\subsubsection{Spectrophotometric titrations of free ligands with dioxobis(2,4-pentanedionato)} molybdenum (VI) $\left[\mathrm{MoO}_{2}(\mathrm{acac})_{2}\right]$

Addition of $\left[\mathrm{MoO}_{2}(\mathrm{acac})_{2}\right]$ yielded hypochromic changes in the UV/Vis spectra of aqueous solutions of free ligands $\mathbf{H}_{2} \mathbf{L}^{\mathbf{1}}-\mathbf{H}_{2} \mathbf{L}^{\mathbf{8}}$. The most prominent changes were observed for free ligand $\mathbf{H}_{2} \mathbf{L}^{\mathbf{1}}$ (Fig. 7). Furthermore, addition of $\left[\mathrm{MoO}_{2}(\text { acac })_{2}\right]$ resulted in strong quenching of free ligands fluorescence (Fig. 8). Stability constants $(K s)$ and the stoichiometries of L/Mo complexes were obtained by processing the titration data with SPECFIT program [28] (Table 6).

\section{Figure 7.}

\section{Figure 8.}

\section{TABLE 6}

Results presented in Table 6 revealed that for all ligands except $\mathbf{H}_{2} \mathbf{L}^{\mathbf{8}}$ best fit was obtained for 1:1 Mo:ligand stoichiometry, either as only possible result $\left(\mathbf{H}_{2} \mathbf{L}^{\mathbf{1}}\right.$ and $\left.\mathbf{H}_{2} \mathbf{L}^{\mathbf{6}}\right)$ or in combination with 2:1 Mo:ligand stoichiometry $\left(\mathbf{H}_{2} \mathbf{L}^{2}, \mathbf{H}_{2} \mathbf{L}^{3}, \mathbf{H}_{2} \mathbf{L}^{4}, \mathbf{H}_{2} \mathbf{L}^{5}\right.$, 
$\left.\mathbf{H}_{2} \mathbf{L}^{7}\right)$. Processing of some titrations gave two equally possible solutions $\left(\mathbf{H}_{2} \mathbf{L}^{3}, \mathbf{H}_{2} \mathbf{L}^{4}\right.$, $\mathbf{H}_{2} \mathbf{L}^{5}, \mathbf{H}_{2} \mathbf{L}^{7}$ ) among which only for $\mathbf{H}_{2} \mathbf{L}^{5}$ it was possible to neglect formation of 2:1 Mo:ligand stoichiometry due to the exclusive result of UV/Vis titration. Therefore, according to here presented results it is not possible to distinguish for $\mathbf{H}_{2} \mathbf{L}^{3}, \mathbf{H}_{2} \mathbf{L}^{4}$, $\mathbf{H}_{2} \mathbf{L}^{7}$ whether one or two complexes are formed.

Comparison of titration results (Table 6) with UV/Vis and fluorimetric spectra of 1-8 complexes in water revealed several distinct differences between complexes prepared by titration and complexes resulting from dissolving the solid samples: a) batochromic shift of the free ligand UV/Vis spectrum observed in titration experiments (e.g. Fig. 7) was not present in comparison of UV/Vis spectrum of dissolved molybdenum complex $\mathbf{1}$ with the UV/Vis spectrum of free $\mathbf{H}_{2} \mathbf{L}^{1}$; b) in UV/Vis titrations only hypochromic effects were observed, which does not agree with data presented in Table 5, in which some complexes have higher $\varepsilon$ values than corresponding free ligands; c) addition of $\left[\mathrm{MoO}_{2}(\mathrm{acac})_{2}\right]$ resulted in quenching of ligands fluorescence exclusively, in contrast to data presented on Fig. 8, according to which some complexes have stronger emission than corresponding free ligands. According to these differences, it is obvious that species resulting from dissolving solid complexes are not the same as obtained from titration results. Most probably the diketonate $\left[\mathrm{MoO}_{2}(\mathrm{acac})_{2}\right]$ was rapidly hydrolyzed in aqueous solution yielding different species as it was known from the literature [35]. Therefore, determined stability constants (Table 6) cannot be used to exactly calculate percentage of dissociation of $\mathbf{1 - 8}$ complexes upon dissolving them in water. Since there is no other experimental approach available to examine dissociation of $\mathbf{1 - 8}$ complexes in water, it is only possible to roughly estimate (according to $\log K s$ values in Table 6) 
that at biologically relevant conditions $\left(\mathrm{c}\left(\left[\mathrm{MoO}_{2} \mathrm{~L}^{1-8}\right]\right)=10^{-6}-10^{-5} \mathrm{~mol} \mathrm{dm}^{-3}\right)$ at least $10 \%\left(\mathbf{H}_{2} \mathbf{L}^{\mathbf{1}}, \mathbf{H}_{2} \mathbf{L}^{\mathbf{5}}\right)$ up to $50 \%\left(\mathbf{H}_{2} \mathbf{L}^{\mathbf{2}}, \mathbf{H}_{2} \mathbf{L}^{3}, \mathbf{H}_{2} \mathbf{L}^{4}, \mathbf{H}_{2} \mathbf{L}^{6}, \mathbf{H}_{2} \mathbf{L}^{7}, \mathbf{H}_{2} \mathbf{L}^{\mathbf{8}}\right)$ was present in a form of complex with $\mathrm{Mo}(\mathrm{VI})$.

\subsection{Interactions of 1-8 complexes with ct-DNA}

Interactions of complexes $\mathbf{2}$ and $\mathbf{4}$ (chosen as the representatives since their free ligands $\mathbf{H}_{2} \mathbf{L}^{2}$ and $\mathbf{H}_{2} \mathbf{L}^{4}$ were previously studied for interactions with DNA [16]) with ct-DNA were studied by thermal denaturation experiments and UV/Vis titrations.

Addition of ct-DNA didn't yield any measurable change in the UV/Vis spectra of $\mathbf{2}$ and

4, similar as observed for their free ligands $\mathbf{H}_{2} \mathbf{L}^{2}$ and $\mathbf{H}_{2} \mathbf{L}^{4}$. Furthermore, thermal denaturation experiments done at ratios $r_{[2,4]} /$ [ct-DNA $]=0.3$ didn't alter thermal denaturation properties of ct-DNA.

The obtained results suggest that complexes $\mathbf{2}$ and $\mathbf{4}$ do not interact with ct-DNA. This result would imply that introduction of positive charge (by Mo(VI)) does not increase affinity of neutral ligands $\mathbf{H}_{2} \mathbf{L}^{2}$ and $\mathbf{H}_{2} \mathbf{L}^{4}$ toward ct-DNA sufficiently for biological relevance.

\subsection{The effect of thiosemicarbazonato molybdenum(VI) complexes 1-8 on the} proliferation of tumor and normal cells

Complexes 1-8 were tested for their potential antiproliferative effects using MTT test (as described in the Experimental section) on a panel of 6 human cell lines, 5 of which 
were derived from different cancer types including HeLa (cervical carcinoma), MCF-7 (breast carcinoma), SW620 (colon carcinoma), MiaPaCa-2 (pancreatic carcinoma), Hep-2 (laryngeal carcinoma) and one from normal diploid fibroblasts, WI 38 (Table 7). All tested compounds showed noticeable antiproliferative effect having $\mathrm{IC}_{50}$ values in the low micromolar, or submicromolar range (Table 7), whereby 5 and $\mathbf{7}$ had the most prominent activity. However, the activity of thiosemicarbazonato molybdenum(VI) complexes are almost completely identical to the activity of their corresponding ligands described previously [16]. Therefore, it seems that molybdenum does not improve the cytotoxic effect of thiosemicarbazones, which apparently have very strong activity on their own, or alternatively the fraction of $\mathbf{1 - 8}$ complexes is too small in the biological relevant conditions, to induce significant effects.

\section{TABLE 7}

\section{Conclusions}

The new molybdenum(VI) complexes revealed that thiosemicarbazonato ligands are coordinated to molybdenum as tridentate $O N S$-donors. Octahedral coordination of each Mo atom in $\left[\mathrm{MoO}_{2} \mathrm{~L}^{2}\left(\mathrm{CH}_{3} \mathrm{OH}\right)\right] \cdot \mathrm{CH}_{3} \mathrm{OH}(\mathbf{2 a})$ in solid state was determined by $\mathrm{X}$-ray crystallography and all complexes were in detail characterized by means of chemical and TG analyses and IR spectroscopy. In DMSO- $d_{6}$ solution NMR spectra of $\mathbf{1 - 3}$ complexes revealed distinct differences in comparison with corresponding free ligands. The characterisation of $\mathbf{1 - 8}$ complexes in aqueous medium by means of UV/Vis and fluorescence spectrophotometry revealed that upon dissolving 1-8 complexes in water, 
most likely to some extent dissociation took place. Antiproliferative effects of 1-8 complexes on the human cell lines were identical to the activity of their corresponding ligands described previously [16]. That could be attributed to either: a) partial dissociation of 1-8 complexes under biologically relevant conditions, resulting in concentration of 1-8 complexes too low for significant biological contribution; or b) the molybdenum(VI) complexes does not improve the cytotoxic effect of thiosemicarbazones, which apparently have very strong activity on their own.

\section{Acknowledgments}

We wish to thank Prof. N. Strukan for the collection of X-ray data for compounds 2a and $\mathbf{H}_{2} \mathbf{L}^{2}$. Financial support for this research was provided by Ministry of Science and Technology of the Republic of Croatia (Grants No. 119-1101342-1082, 119-11930791084, 098-0982914-2918, 098-0982464-2514).

\section{Supplementary Material Available:}

Crystallographic data have been deposited with the CCDC, 12 Union Road, Cambridge, CB2 1EZ, UK (fax: +44-1223-366033; e-mail: deposit@ccdc.cam.ac.uk or www://www.ccdc.cam.ac.uk) and are available on request, quoting the deposition number 702874 for the compound $\mathbf{H}_{2} \mathbf{L}^{2}$ and 702875 for the compound $\mathbf{2 a}$. 


\section{References}

[1] P. I. da S. Maia, F. R. Pavan, C. Q. F. Leite, S. S. Lemos, G. F. de Sousa, A. A. Batista, O. R. Nascimento, J. Ellena, E. E. Castellano, E. Niquet, V. M. Deflon, Polyhedron 28 (2009) 398-406.

[2] D. X. West, A. E. Liberta, S. B. Padhye, R. C. Chikate, P. B. Sonawane, A. S. Kunmbhar, R. G. Yerande, Coord. Chem. Rev. 123 (1993) 49-71.

[3] D. Kovale-Demertzi, D. Domopoulou, M. Demertzis, C. P. Raptopoulou, A. Terzis, Polyhedron 13 (1994) 1917-1025.

[4] D. B. Lovejoy, D. R. Richardson, Blood 100 (2002) 666-676.

[5] N. Farrell, Coord. Chem. Rev. 232 (2002) 1-4.

[6] M. Belicchi-Ferrari, F. Bisceglie, C. Casoli, S. Durot, I. Morgenstern-Badarau, G. Pelosi, E. Pilotti, S. Pinelli, P. Tarasconi, J. Med. Chem. 48 (2005) 1671-1675.

[7] Z. Afrasiabi, E. Sinn, J. Chen, Y. Ma, A. L. Rheingold, L. N. Zakharov, N. Rath, S. Padhye, Inorg. Chim. Acta 357 (2004) 271-278.

[8] R. R. Mendel, F. Bittner, Biochim. Biophys. Acta - Mol. Cell Res. 1763 (2006) 621-635.

[9] C. D. Brondino, M. J. Romão, I. Moura, J. JG Moura, Curr. Opin. Chem. Biol. 10 (2006) 109-114.

[10] G. Hou, R. Dick, C. Zeng, G. J.Brewer, Transl. Res. 149 ( 2007) 260-4.

[11] B. Hassouneh, M. Islam, T. Nagel, Q. Pan, S. D. Merajver, T. N. Teknos, Mol. Cancer Ther. 6 (2007) 1039-45.

[12] H. Yanagiea, A. Ogatab, S. Mitsuib, T. Hisaa, T. Yamaseb, M. Eriguchia, Biomed. Pharmacother. 60 (2006) 349-52. 
[13] T. Yamase, Mol. Eng. 3 (1993) 241-262.

[14] M. Cindrić, T. Kajfež Novak, S. Kraljević, M. Kralj, B. Kamenar, Inorg. Chim. Acta 359 (2006) 1673-1680.

[15] P. Ghosh, O. J. D’Cruz, R. K. Narla, F. M. Uckun, Clin. Cancer Res. 6 (2000) $1536-1545$.

[16] I. Đilović, M. Rubčić, V. Vrdoljak, S. Kraljević Pavelić, M. Kralj, I. Piantanida, M. Cindrić, Bioorg. Med. Chem. 16 (2008) 5189-5198.

[17] M. Cindrić, V. Vrdoljak, N. Strukan, B. Kamenar, Polyhedron 24 (2005) 369-376.

[18] V. Vrdoljak, M. Cindrić, D. Matković-Čalogović, B. Prugovečki, P. Novak, B. Kamenar, Z. Anorg. Allg. Chem. 631 (2005) 928-936.

[19] V. Vrdoljak, M. Cindrić, D. Milić, D. Matković-Čalogović, P. Novak, B. Kamenar, Polyhedron 24 (2005) 1717-1726.

[20] G. J.-J. Chen, J. W. McDonald, W. E. Newton, Inorg. Chem. 15 (1976) 26122615.

[21] V. Vrdoljak, I. Đilović, M. Cindrić, D. Matković-Čalogović, N. Strukan, A. Gojmerac-Ivšić, P. Novak, Polyhedron 28 (2009) 959 - 965.

[22] Oxford Diffraction (2003). Oxford Diffraction Ltd., Xcalibur CCD system, CrysAlis Software system, Version 1.170.

[23] G. M. Sheldrick, SHELXS, University of Göttingen, Germany, 1997.

[24] G. M. Sheldrick, SHELXL97, University of Göttingen, Germany, 1997.

[25] L. J. Farrugia, J. Appl. Crystallogr. 32 (1999) 837-838.

[26] L. J. Farrugia, J. Appl. Crystallogr. 30 (1997) 565. 
[27] C. F. Macrae, P. R. Edgington, P. McCabe, E. Pidcock, G. P. Shields, R. Taylor, M. Towler, J. van de Streek, J. Appl. Cryst. 39 (2006) 453-457.

[28] Specfit Global Analysis, a Program for Fitting, Equilibrium and Kinetic Systems, Using Factor Analysis \& Marquardt Minimization; a) M. Maeder, A. D. Zuberbuehler, Anal. Chem. 62 (1990) 2220-2224.; b) H. Gampp, M. Maeder, C .J. Meyer, A.D. Zuberbuehler, Talanta 32 (1985) 257-264.

[29] N. Kathale, N. S. Rao, N. N. Rao, K. N. Munshi, Synth. React. Inorg. Met-Org. Chem. 31 (2001) 859-871.

[30] S. Bhattacharjee, R. Bhattacharjee, J. Chem. Soc., Dalton Trans. (1992) 1357-1364

[31] E. B. Seena, B. N. Bessy Raj, M. R. Prathapachandra Kurup, E. Suresh, J. Chem. Cryst. 38 (2008) 93-96.

[32] Cambridge Structural Database, V5.28, Cambridge Crystallographic Data Centre, 12 Union Road, Cambridge, England, November 2006.

[33] A. Rana, R. Dinda, P. Segupta, S. Ghosh, L. R. Falvello, Polyhedron 21 (2002) 1023-1030.

[34] M. Cindrić, M. Rubčić, I. Đilović, G. Giester, B. Kamenar, Croat. Chem. Acta 80 (2007) 583-590.

[35] M. R. Pedrosa, J. Escribano, R. Aguado, V. Díez, R. Sanz, F. J. Arnáiz, Polyhedron 26 (2007) 3695-3702. 
Table 1. Thermoanalytical data for the complexes $\left[\mathrm{MoO}_{2} \mathrm{~L}\right]_{\mathrm{n}}$, $\left[\mathrm{MoO}_{2} \mathrm{~L}\left(\mathrm{CH}_{3} \mathrm{OH}\right)\right]$.

\begin{tabular}{|c|c|c|c|c|c|}
\hline \multirow[b]{2}{*}{ Formula } & \multirow[b]{2}{*}{ Comp. } & \multicolumn{2}{|c|}{ Loss of solvent } & \multicolumn{2}{|c|}{ Decomposition } \\
\hline & & $\begin{array}{c}\text { Temperature } \\
\text { range }\left({ }^{\circ} \mathrm{C}\right)\end{array}$ & $\begin{array}{c}\Delta \mathrm{m}(\%) \\
\text { found } \\
\text { (calcd.) }\end{array}$ & $\begin{array}{c}\text { Temperature } \\
\text { range }\left({ }^{\circ} \mathrm{C}\right)\end{array}$ & $\begin{array}{c}\Delta \mathrm{m}(\%) \\
\text { found } \\
\text { (calcd.) }\end{array}$ \\
\hline$\left[\mathrm{MoO}_{2}\left(\mathrm{C}_{12} \mathrm{H}_{16} \mathrm{~N}_{4} \mathrm{OS}\right)\right]_{\mathrm{n}}$ & 1 & --- & --- & $212-475$ & $\begin{array}{c}63.91 \\
(63.31)\end{array}$ \\
\hline$\left[\mathrm{MoO}_{2}\left(\mathrm{C}_{12} \mathrm{H}_{16} \mathrm{~N}_{4} \mathrm{OS}\right)\left(\mathrm{CH}_{3} \mathrm{OH}\right)\right]$ & 1a & $30-90$ & $\begin{array}{c}6.48 \\
(7.55)\end{array}$ & $185-472$ & $\begin{array}{c}66.21 \\
(66.09)\end{array}$ \\
\hline$\left[\mathrm{MoO}_{2}\left(\mathrm{C}_{9} \mathrm{H}_{9} \mathrm{~N}_{3} \mathrm{O}_{2} \mathrm{~S}\right)\right]_{\mathrm{n}}$ & 2 & --- & --- & $255-542$ & $\begin{array}{c}55.76 \\
(55.18)\end{array}$ \\
\hline$\left[\mathrm{MoO}_{2}\left(\mathrm{C}_{9} \mathrm{H}_{9} \mathrm{~N}_{3} \mathrm{O}_{2} \mathrm{~S}\right)\left(\mathrm{CH}_{3} \mathrm{OH}\right)\right]$ & $2 \mathbf{a}$ & $75-131$ & $\begin{array}{c}8.46 \\
(8.36)\end{array}$ & $273-469$ & $\begin{array}{r}62.44 \\
(63.13)\end{array}$ \\
\hline$\left[\mathrm{MoO}_{2}\left(\mathrm{C}_{12} \mathrm{H}_{9} \mathrm{~N}_{3} \mathrm{OS}\right)\right]_{\mathrm{n}}$ & 3 & & & $176-586$ & $\begin{array}{c}61.22 \\
(63.31)\end{array}$ \\
\hline$\left[\mathrm{MoO}_{2}\left(\mathrm{C}_{12} \mathrm{H}_{9} \mathrm{~N}_{3} \mathrm{OS}\right)\left(\mathrm{CH}_{3} \mathrm{OH}\right)\right]$ & 3a & $130-152$ & $\begin{array}{c}7.78 \\
(7.95)\end{array}$ & $225-526$ & $\begin{array}{c}64.31 \\
(64.50)\end{array}$ \\
\hline
\end{tabular}


Table 2. General and crystal data, summary of intensity data collection and structure refinement for the $\mathbf{H}_{2} \mathbf{L}^{2}$ and $\left[\mathrm{MoO}_{2} \mathrm{~L}^{2}\left(\mathrm{CH}_{3} \mathrm{OH}\right)\right] \cdot \mathrm{CH}_{3} \mathrm{OH}(\mathbf{2 a})$.

\begin{tabular}{|c|c|c|}
\hline & $\mathbf{H}_{2} \mathbf{L}^{2}$ & $2 \mathbf{a}$ \\
\hline Empirical formula & $\mathrm{C}_{9} \mathrm{H}_{11} \mathrm{~N}_{3} \mathrm{O}_{2} \mathrm{~S}$ & $\mathrm{C}_{11} \mathrm{H}_{17} \mathrm{MoN}_{3} \mathrm{O}_{6} \mathrm{~S}$ \\
\hline Formula weight & 225.27 & 415.27 \\
\hline Color & Colourless & Red \\
\hline Crystal system, space group & Monoclinic, $P 2_{1} / c$ & Monoclinic, $P 2{ }_{1} / a$ \\
\hline \multicolumn{3}{|l|}{ Unit cell dimensions $\left(\AA,^{\circ}\right)$} \\
\hline$a$ & $7.0724(14)$ & $13.8987(2)$ \\
\hline$b$ & $14.700(3)$ & $7.2884(2)$ \\
\hline$c$ & $10.787(2)$ & $16.3552(3)$ \\
\hline$\beta$ & $108.46(3)$ & $104.6120(10)$ \\
\hline Volume $\left(\AA^{3}\right)$ & $1063.7(4)$ & $1603.18(6)$ \\
\hline$Z$ & 4 & 4 \\
\hline$D_{\text {calc }}\left(\mathrm{g} \mathrm{cm}^{-3}\right)$ & 1.407 & 1.716 \\
\hline$\mu\left(\mathrm{mm}^{-1}\right)$ & 0.288 & 0.979 \\
\hline$F(000)$ & 472 & 836 \\
\hline Reflections collected/unique & $3492 / 1785$ & $9640 / 2798$ \\
\hline Data/restraints/parameters & $1785 / 0 / 170$ & $2798 / 0 / 211$ \\
\hline Goodness-of-fit on $F^{2}$ & 1.102 & 1.113 \\
\hline$R / w R[I>2 \sigma(I)]^{*}$ & $0.0458 / 0.1272$ & $0.0321 / 0.0749$ \\
\hline Largest diff. peak and hole (e $\AA^{-3}$ ) & $0.201 /-0.175$ & $0.655 /-0.636$ \\
\hline
\end{tabular}


Table 3. Selected bond lengths $(\AA)$ and angles $\left(^{\circ}\right)$ for the $\mathbf{H}_{2} \mathbf{L}^{2}$ and $\left[\mathrm{MoO}_{2} \mathrm{~L}^{2}\left(\mathrm{CH}_{3} \mathrm{OH}\right)\right] \cdot \mathrm{CH}_{3} \mathrm{OH}(\mathbf{2 a})$.

\begin{tabular}{|c|c|c|}
\hline & $\mathbf{H}_{2} \mathbf{L}^{2}$ & $2 \mathbf{a}$ \\
\hline $\mathrm{C} 1-\mathrm{S} 1$ & $1.697(3)$ & $1.758(3)$ \\
\hline $\mathrm{C} 1-\mathrm{N} 1$ & $1.320(4)$ & $1.343(4)$ \\
\hline $\mathrm{C} 1-\mathrm{N} 2$ & $1.337(3)$ & $1.310(4)$ \\
\hline $\mathrm{C} 2-\mathrm{C} 3$ & $1.467(4)$ & $1.455(4)$ \\
\hline $\mathrm{C} 2-\mathrm{N} 3$ & $1.268(4)$ & 1.298 \\
\hline C3-C4 & $1.387(4)$ & $1.399(4)$ \\
\hline $\mathrm{C} 4-\mathrm{O} 3$ & $1.356(3)$ & $1.345(4)$ \\
\hline N2-N3 & $1.385(3)$ & $1.401(3)$ \\
\hline Mo1-O1 & & $1.727(2)$ \\
\hline Mo1-O2 & & $1.704(2)$ \\
\hline Mo1-O3 & & $1.922(2)$ \\
\hline Mo1-N3 & & $2.273(3)$ \\
\hline Mo1-S1 & & $2.4317(7)$ \\
\hline Mo1-O5 & & $2.351(2)$ \\
\hline O1-Mo1-O2 & & $105.26(12)$ \\
\hline O1-Mo1-O3 & & $104.65(9)$ \\
\hline O1-Mo1-N3 & & $156.41(10)$ \\
\hline O1-Mo1-O5 & & $83.58(9)$ \\
\hline O1-Mo1-S1 & & $90.20(7)$ \\
\hline O2-Mo1-O3 & & $99.35(10)$ \\
\hline O2-Mo1-N3 & & $95.29(11)$ \\
\hline O2-Mo1-O5 & & $171.14(10)$ \\
\hline O2-Mo1-S1 & & $95.72(8)$ \\
\hline O3-Mo1-N3 & & $82.84(9)$ \\
\hline O3-Mo1-O5 & & $78.49(8)$ \\
\hline O3-Mo1-S1 & & $155.11(7)$ \\
\hline N3-Mo1-O5 & & $75.95(8)$ \\
\hline N3-Mo1-S1 & & $76.13(6)$ \\
\hline O5-Mo1-S1 & & $83.58(6)$ \\
\hline
\end{tabular}


Table 4. ${ }^{1} \mathrm{H}$ and ${ }^{13} \mathrm{C}$ chemical shifts (ppm) of the ligands $\mathbf{H}_{2} \mathbf{L}^{1}-\mathbf{H}_{2} \mathbf{L}^{3}$ and their molybdenum(VI) complexes 1-3 in DMSO- $d_{6}$.

\begin{tabular}{|c|c|c|c|c|c|c|c|c|c|c|c|c|}
\hline \multirow{2}{*}{$\begin{array}{c}\text { Comp. } \\
\text { atom }\end{array}$} & \multicolumn{2}{|c|}{$\mathbf{H}_{2} \mathbf{L}^{1}$} & \multicolumn{2}{|c|}{1} & \multicolumn{2}{|c|}{$\mathbf{H}_{2} \mathbf{L}^{2}$} & \multicolumn{2}{|r|}{2} & \multicolumn{2}{|c|}{$\mathbf{H}_{2} \mathbf{L}^{3}$} & \multicolumn{2}{|c|}{3} \\
\hline & ${ }^{1} \mathrm{H}$ & ${ }^{13} \mathrm{C}$ & ${ }^{1} \mathrm{H}$ & ${ }^{13} \mathrm{C}$ & ${ }^{1} \mathrm{H}$ & ${ }^{13} \mathrm{C}$ & ${ }^{1} \mathrm{H}$ & ${ }^{13} \mathrm{C}$ & ${ }^{1} \mathrm{H}$ & ${ }^{13} \mathrm{C}$ & ${ }^{1} \mathrm{H}$ & ${ }^{13} \mathrm{C}$ \\
\hline 1 & 8.19 & 142.45 & 8.21 & 151.19 & 8.40 & 139.83 & 8.43 & 150.47 & 9.05 & 142.92 & 9.22 & 146.32 \\
\hline 2 & 11.07 & & & & 11.39 & & & & 11.38 & & & \\
\hline 3 & & 176.55 & & 162.60 & & 178.05 & & 166.01 & & 177.41 & & 165.87 \\
\hline 4 & 7.87 & & 6.66 & & 8.10 & & & 6.95 & 8.20 & & 7.18 & \\
\hline & 7.66 & & & & 7.88 & & & & 7.81 & & & \\
\hline 5 & & 158.26 & & 160.38 & & 146.34 & & 148.57 & & 156.49 & & 159.70 \\
\hline 6 & 6.09 & 97.40 & 6.06 & 98.64 & & 148.26 & & 148.16 & 7.19 & 118.23 & 7.14 & 120.05 \\
\hline 7 & & 150.20 & & 151.88 & 6.96 & 113.19 & 7.10 & 115.15 & 7.88 & 132.35 & 7.99 & 133.91 \\
\hline 8 & 6.21 & 104.08 & 6.34 & 105.18 & 6.77 & 119.33 & 6.92 & 120.37 & & 127.95 & & 128.77 \\
\hline 9 & 7.52 & 129.12 & 7.28 & 134.60 & 7.53 & 118.52 & 7.15 & 124.41 & 7.85 & 128.56 & 7.92 & 129.09 \\
\hline 10 & & 107.51 & & 108.96 & & 121.14 & & 121.20 & 7.38 & 123.33 & 7.45 & 124.33 \\
\hline 11 & 3.33 & 43.94 & 3.70 & 43.84 & 3.81 & 56.25 & 3.77 & 55.60 & 7.56 & 127.75 & 7.61 & 128.23 \\
\hline 12 & 1.10 & 12.69 & 1.10 & 12.47 & & & & & 8.51 & 122.70 & 8.26 & 121.37 \\
\hline 13 & & & & & & & & & & 131.40 & & 132.25 \\
\hline 14 & & & & & & & & & & 109.61 & & 112.31 \\
\hline $\mathrm{OH}$ & 9.61 & & & & 9.17 & & & & 10.48 & & & \\
\hline
\end{tabular}


Table 5. Electronic absorption maxima and molar extinction coefficients of the ligands ${ }^{\mathrm{a}}$ $\mathbf{H}_{2} \mathbf{L}^{1}-\mathbf{H}_{2} \mathbf{L}^{8}$ and their molybdenum(VI) complexes 1-8 in water.

\begin{tabular}{|c|c|c|c|c|c|}
\hline & \multicolumn{2}{|c|}{$\left[\mathrm{MOO}_{2} \mathrm{~L}\left(\mathrm{CH}_{3} \mathrm{OH}\right)\right]$} & \multicolumn{3}{|c|}{${ }^{\mathrm{A}} \mathbf{H}_{2} \mathbf{L}$} \\
\hline & $\lambda_{\max } / \mathrm{nm}$ & $\varepsilon / \mathrm{mmol}^{-1} \mathrm{~cm}^{2}$ & & $\lambda_{\max } / \mathrm{nm}$ & $\varepsilon / \mathrm{mmol}^{-1} \mathrm{~cm}^{2}$ \\
\hline 1 & 368 & $56.26 \pm 1.26$ & $\mathbf{H}_{2} \mathbf{L}^{1}$ & 368 & $40.98 \pm 1.57$ \\
\hline 2 & 307 & $23.37 \pm 0.28$ & $\mathbf{H}_{2} \mathbf{L}^{2}$ & 307 & $24.67 \pm 0.28$ \\
\hline \multirow[t]{2}{*}{3} & 326 & $25.17 \pm 0.10$ & \multirow{2}{*}{$\mathbf{H}_{2} \mathbf{L}^{3}$} & 326 & $24.42 \pm 0.26$ \\
\hline & 361 & $27.91 \pm 0.14$ & & 361 & $27.10 \pm 0.30$ \\
\hline \multirow[t]{2}{*}{4} & 300 & $29.87 \pm 0.11$ & \multirow{2}{*}{$\mathbf{H}_{2} \mathbf{L}^{4}$} & 300 & $21.68 \pm 0.07$ \\
\hline & 325 & $28.19 \pm 0.12$ & & 325 & $20.51 \pm 0.06$ \\
\hline 5 & 376 & $30.60 \pm 1.49$ & $\mathbf{H}_{2} \mathbf{L}^{5}$ & 376 & $40.50 \pm 1.53$ \\
\hline 6 & 314 & $37.32 \pm 0.62$ & $\mathbf{H}_{2} \mathrm{~L}^{6}$ & 314 & $35.93 \pm 1.26$ \\
\hline \multirow[t]{2}{*}{7} & 328 & $15.64 \pm 0.54$ & \multirow{2}{*}{$\mathbf{H}_{2} \mathbf{L}^{7}$} & 328 & $9.46 \pm 0.41$ \\
\hline & 363 & $18.49 \pm 0.81$ & & 363 & $10.25 \pm 0.59$ \\
\hline \multirow[t]{2}{*}{8} & 303 & $40.44 \pm 0.33$ & \multirow{2}{*}{$\mathbf{H}_{2} \mathbf{L}^{8}$} & 303 & $29.86 \pm 0.42$ \\
\hline & 329 & $43.77 \pm 0.35$ & & 329 & $32.02 \pm 0.48$ \\
\hline
\end{tabular}

\footnotetext{
${ }^{\text {a }}$ Published data [16].
} 
Table 6. Binding constants $(\log K s)^{\mathrm{a}}$ calculated by SPECFIT program [28] for various Mo:ligand stoichiometries from the UV/Vis and fluorimetric titrations of free ligands with $\left[\mathrm{MoO}_{2}(\mathrm{acac})_{2}\right]$.

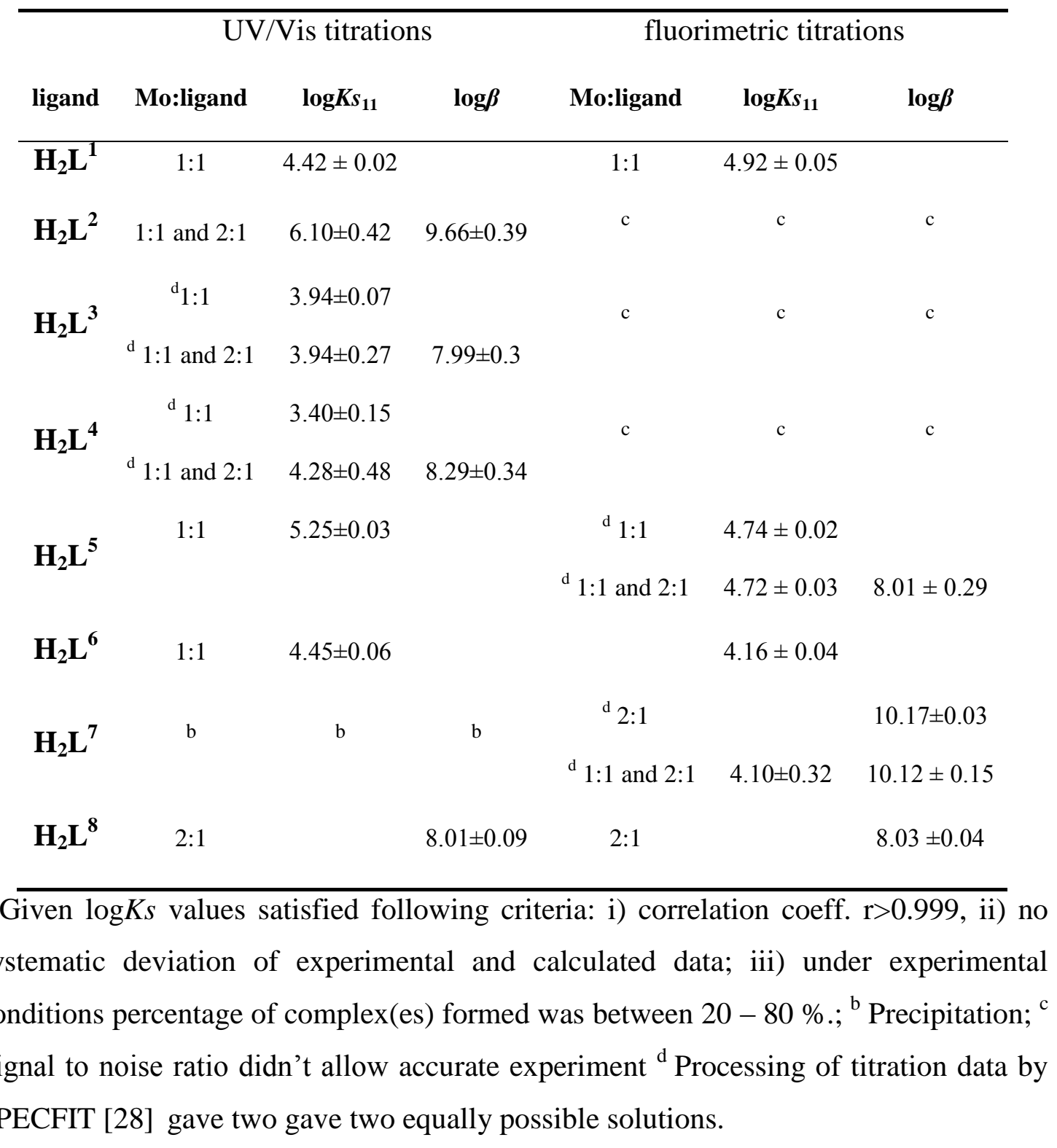


Table 7. In vitro inhibition of complexes 1-8 on the growth of tumor cells and normal human fibroblasts (WI 38).

\section{$\mathrm{IC}_{50}(\mu \mathrm{M})^{[\mathrm{a}]}$}

Compd.

Hep-2 HeLa MiaPaCa-2 SW620 MCF-7 WI 38

\begin{tabular}{ccccccc}
\hline $\mathbf{1}$ & $1 \pm 0.2$ & $2 \pm 0,8$ & $>5$ & $3 \pm 1$ & $0.2 \pm 0.4$ & $0.2 \pm 0.02$ \\
$\mathbf{2}$ & $3.2 \pm 1$ & $\geq 5$ & $0.6 \pm 0.4$ & $\geq 5$ & $0.2 \pm 0.3$ & $0.6 \pm 0.04$ \\
$\mathbf{3}$ & $\geq 5$ & $\geq 5$ & $>5$ & $>5$ & $>5$ & $2 \pm 0.7$ \\
$\mathbf{4}$ & $>5$ & $>5$ & $>5$ & $>5$ & $\geq 5$ & $1 \pm 0.8$ \\
$\mathbf{5}$ & $0.6 \pm 0.08$ & $0.7 \pm 0.2$ & $0.5 \pm 0.2$ & $0.7 \pm 0.1$ & $0.7 \pm 0.02$ & $0.6 \pm 0.2$ \\
$\mathbf{6}$ & $3 \pm 1$ & $1 \pm 0.3$ & $2 \pm 0.6$ & $2 \pm 0.001$ & $2 \pm 0.2$ & $\geq 5$ \\
$\mathbf{7}$ & $0.6 \pm 0.3$ & $0.4 \pm 0.1$ & $0.9 \pm 0.04$ & $0.5 \pm 0.2$ & $0.9 \pm 0.06$ & $0.6 \pm 0.3$ \\
$\mathbf{8}$ & $2 \pm 0.07$ & $2 \pm 0.1$ & $3 \pm 0.5$ & $2 \pm 0.1$ & $2 \pm 0.2$ & $2 \pm 1$ \\
cisplatin & $3 \pm 1$ & $4 \pm 2$ & $5 \pm 2$ & $8 \pm 6$ & $12 \pm 5$ & $21 \pm 15$ \\
etoposide & $\mathrm{N} . \mathrm{T} .{ }^{[\mathrm{b}]}$ & $3 \pm 1$ & $15 \pm 14$ & $20 \pm 3$ & $50 \pm 20$ & $\mathrm{~N} . \mathrm{T} .{ }^{[\mathrm{b}]}$ \\
doxorubicin & $0.04 \pm 0.01$ & $0.04 \pm 0.01$ & $0.02 \pm 0.01$ & $0.02 \pm 0.01$ & $0.04 \pm 0.01$ & $0.1 \pm 0.01$ \\
\hline
\end{tabular}

[a] - $\mathrm{IC}_{50}$; the concentration that causes a $50 \%$ reduction of the cell growth

${ }^{[b]}-$ N.T.; not tested 


\section{Figure and Scheme captions}

Scheme 1. General synthetic procedure for studied molybdenum(VI) complexes, $\left[\mathrm{MoO}_{2} \mathrm{~L}\right]_{\mathrm{n}}(\mathbf{1 - 8})$ and $\left[\mathrm{MoO}_{2} \mathrm{~L}\left(\mathrm{CH}_{3} \mathrm{OH}\right)\right](\mathbf{1 a - 3 a})$.

Scheme 2. Numbering of $\mathrm{C}$ and $\mathrm{H}$ atoms.

Figure 1. A view of the molecular structure of $\mathbf{H}_{2} \mathbf{L}^{2}$, showing atom labelling scheme. Displacement ellipsoids are drawn at the $50 \%$ probability level and $\mathrm{H}$ atoms are presented as spheres of arbitrary size.

Figure 2. The crystal packing of $\mathbf{H}_{2} \mathbf{L}^{2}$ viewed down $a$ axis. Layers of molecules are represented in different colours. Upper layer is shown in blue, bottom in red. Hydrogen bonds are represented as dashed sticks. Symmetry codes are mentioned above in the main text.

Figure 3. View of the molecular structure of $\left[\mathrm{MoO}_{2} \mathrm{~L}^{2}\left(\mathrm{CH}_{3} \mathrm{OH}\right)\right] \cdot \mathrm{CH}_{3} \mathrm{OH}$ (2a) with atom-labelling scheme. Thermal ellipsoids are shown at 50\% probability level and hydrogen atoms are omitted for clarity.

Figure 4. The crystal packing of $\left[\mathrm{MoO}_{2} \mathrm{~L}^{2}\left(\mathrm{CH}_{3} \mathrm{OH}\right)\right] \cdot \mathrm{CH}_{3} \mathrm{OH}(\mathbf{2 a})$. View is projected down the $b$ axis. $\mathrm{H}$ atoms not involved in hydrogen bonding are omitted for clarity. Symmetry codes: $i=1 / 2-x, y-1 / 2,1-z ; i i=-x, 1-y, 1-z$.

Figure 5. The UV/Vis spectra of $\mathbf{1 - 8}$ complexes in water. 
Figure 6. The fluorimetric spectra of $\mathbf{1 - 8}$ complexes and corresponding free ligands $\mathbf{H}_{2} \mathbf{L}^{1}-\mathbf{H}_{2} \mathbf{L}^{\mathbf{8}}$ in water $\left(c=5 \times 10^{-6} \mathrm{~mol} \mathrm{dm}^{-3}, \lambda_{\text {exc }}\right.$ see maxima at longer wavelengths in Table 5).

Figure 7. A) UV/Vis titration of free ligand $\mathbf{H}_{2} \mathbf{L}^{1}\left(c=1.29 \times 10^{-5} \mathrm{~mol} \mathrm{dm}^{-3}\right)$ with $\left[\mathrm{MoO}_{2}(\mathrm{acac})_{2}\right]\left(c=0-1.2 \times 10^{-4} \mathrm{~mol} \mathrm{dm}{ }^{-3}\right)$ in water; $\left.\mathrm{B}\right)$ distribution diagram of species present during titration; C) agreement of experimental and calculated values for 1:1 stoichiometry.

Figure 8. A) Fluorimetric titration of free ligand $\mathbf{H}_{2} \mathbf{L}^{1}\left(c=2.58 \times 10^{-6} \mathrm{~mol} \mathrm{dm}^{-3}\right)$ with $\left[\mathrm{MoO}_{2}(\mathrm{acac})_{2}\right]\left(c=0-6.0 \times 10^{-5} \mathrm{~mol} \mathrm{dm}{ }^{-3}\right)$ in water; $\left.\mathrm{B}\right)$ distribution diagram of species present during titration; C) agreement of experimental and calculated values for $1: 1$ stoichiometry. 


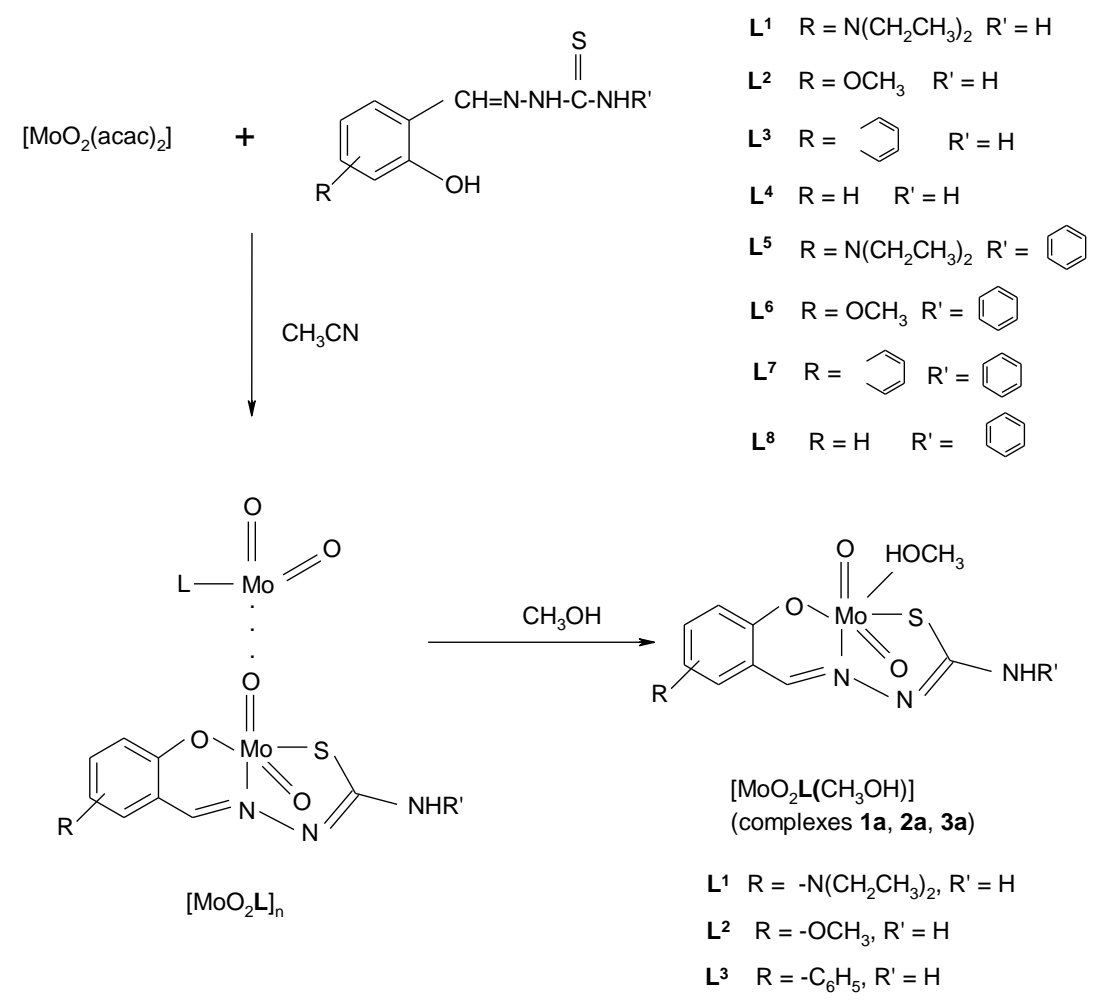

Scheme 1.
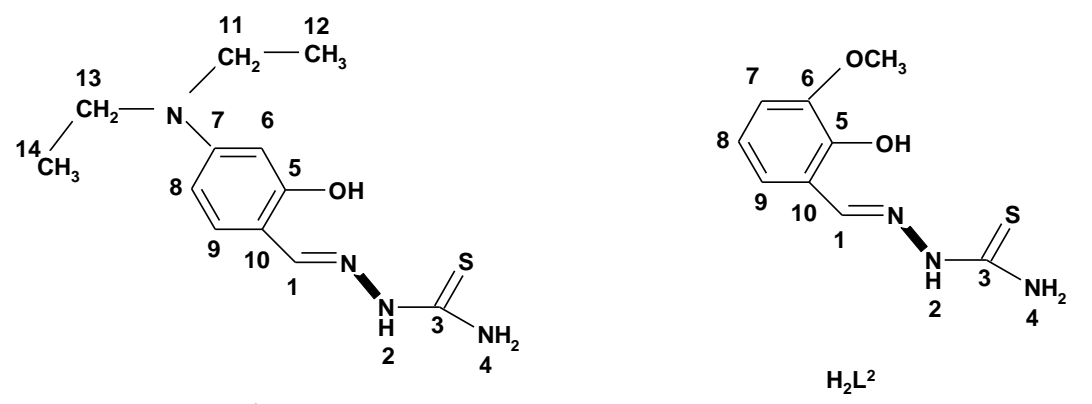

$\mathrm{H}_{2} \mathrm{~L}^{\mathbf{1}}$

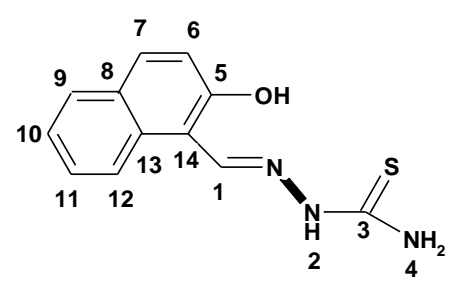

$\mathrm{H}_{2} \mathrm{~L}^{3}$

Scheme 2. 


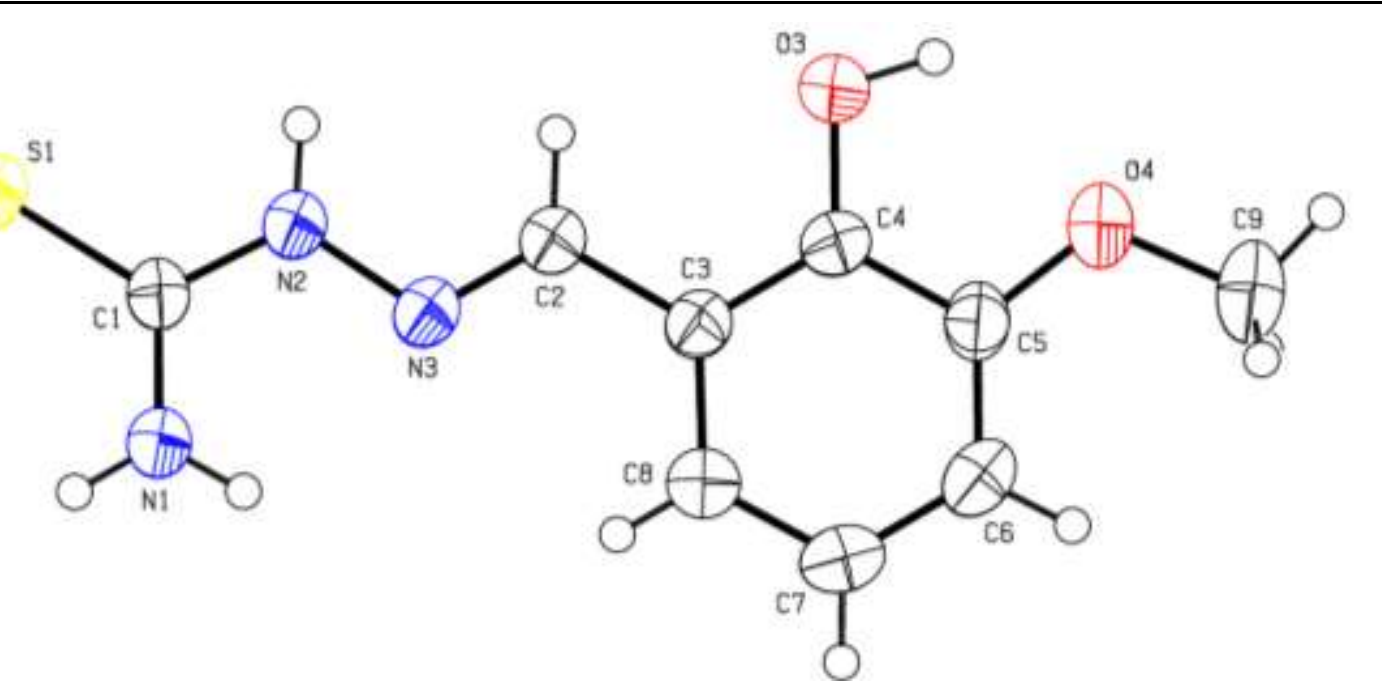

Figure 1.

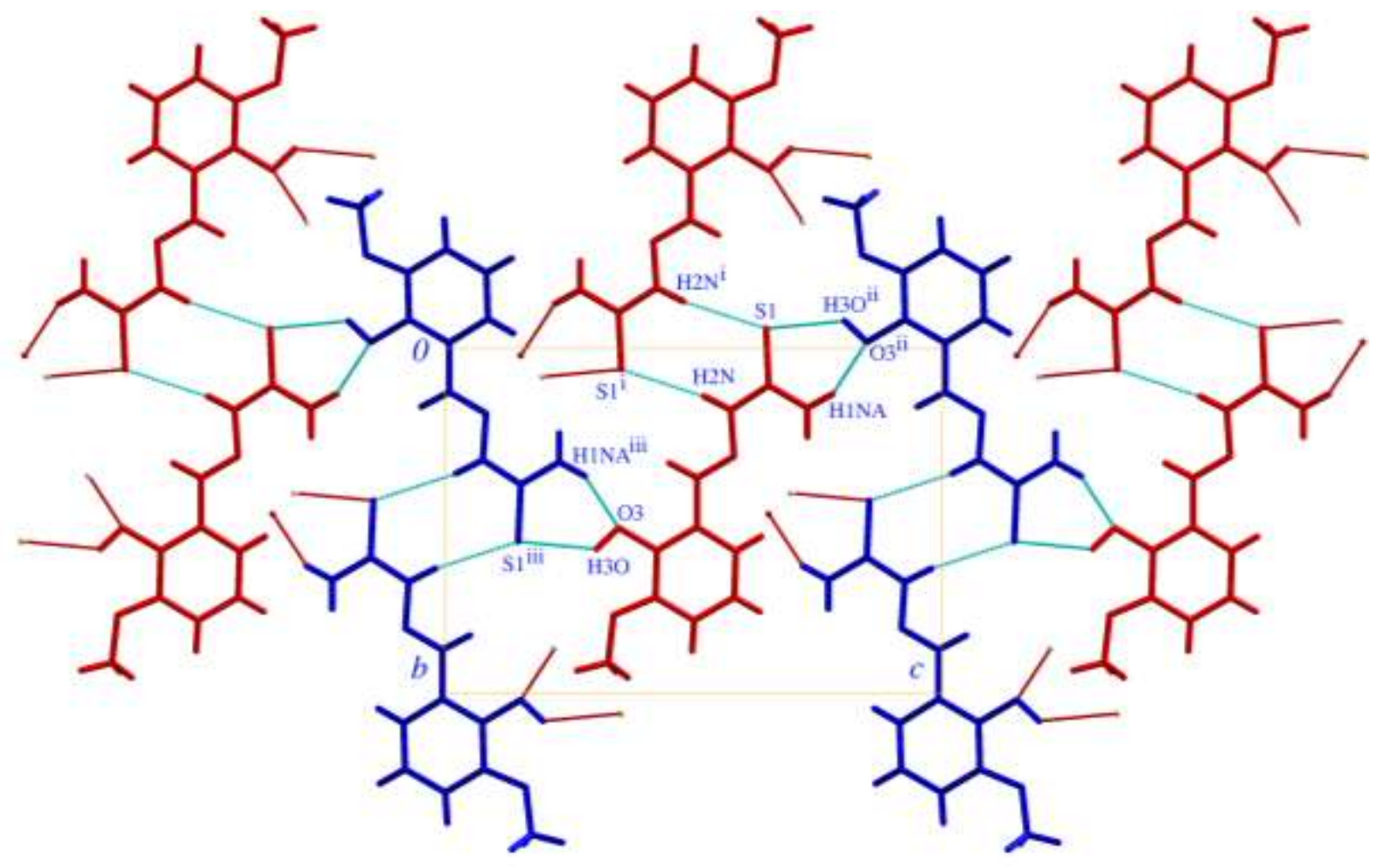

Figure 2. 


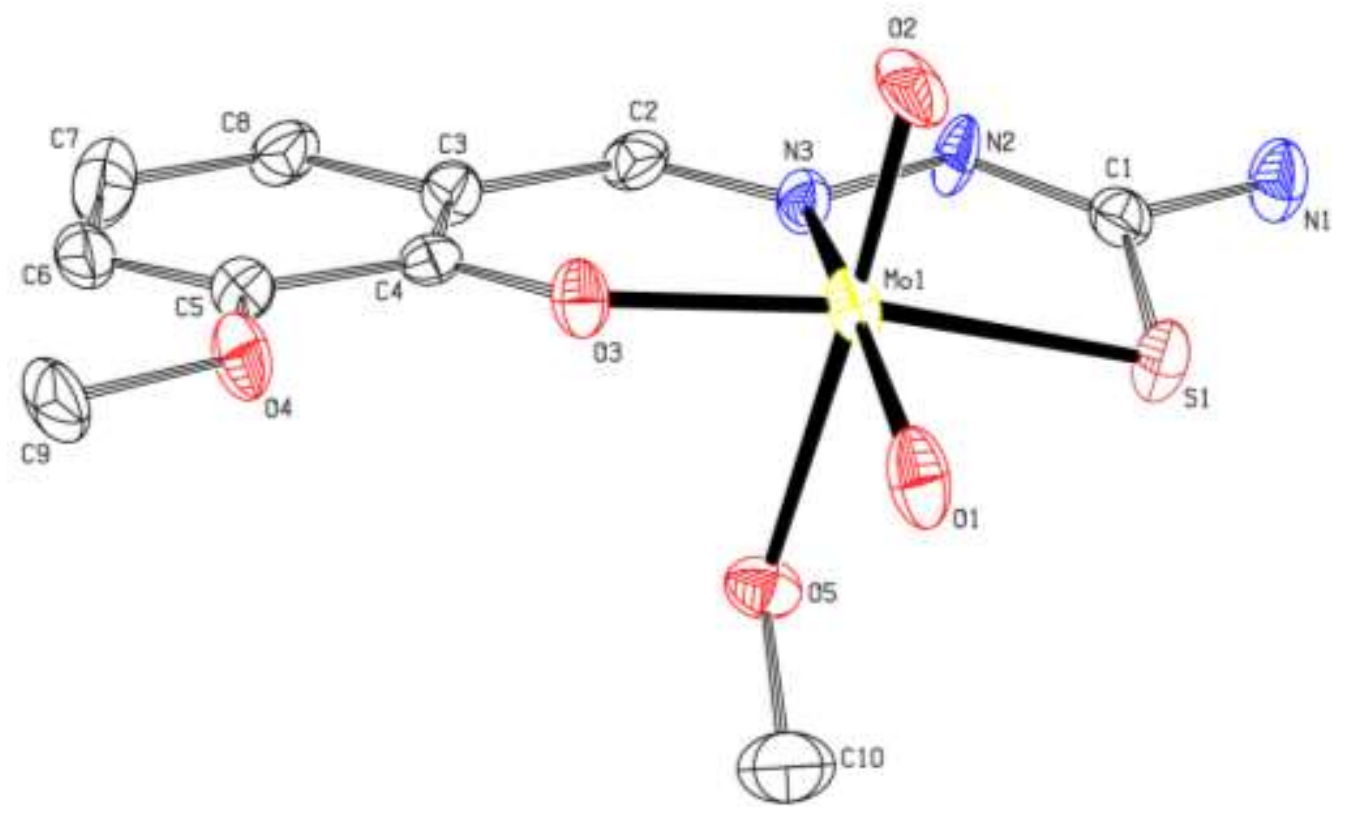

Figure 3.

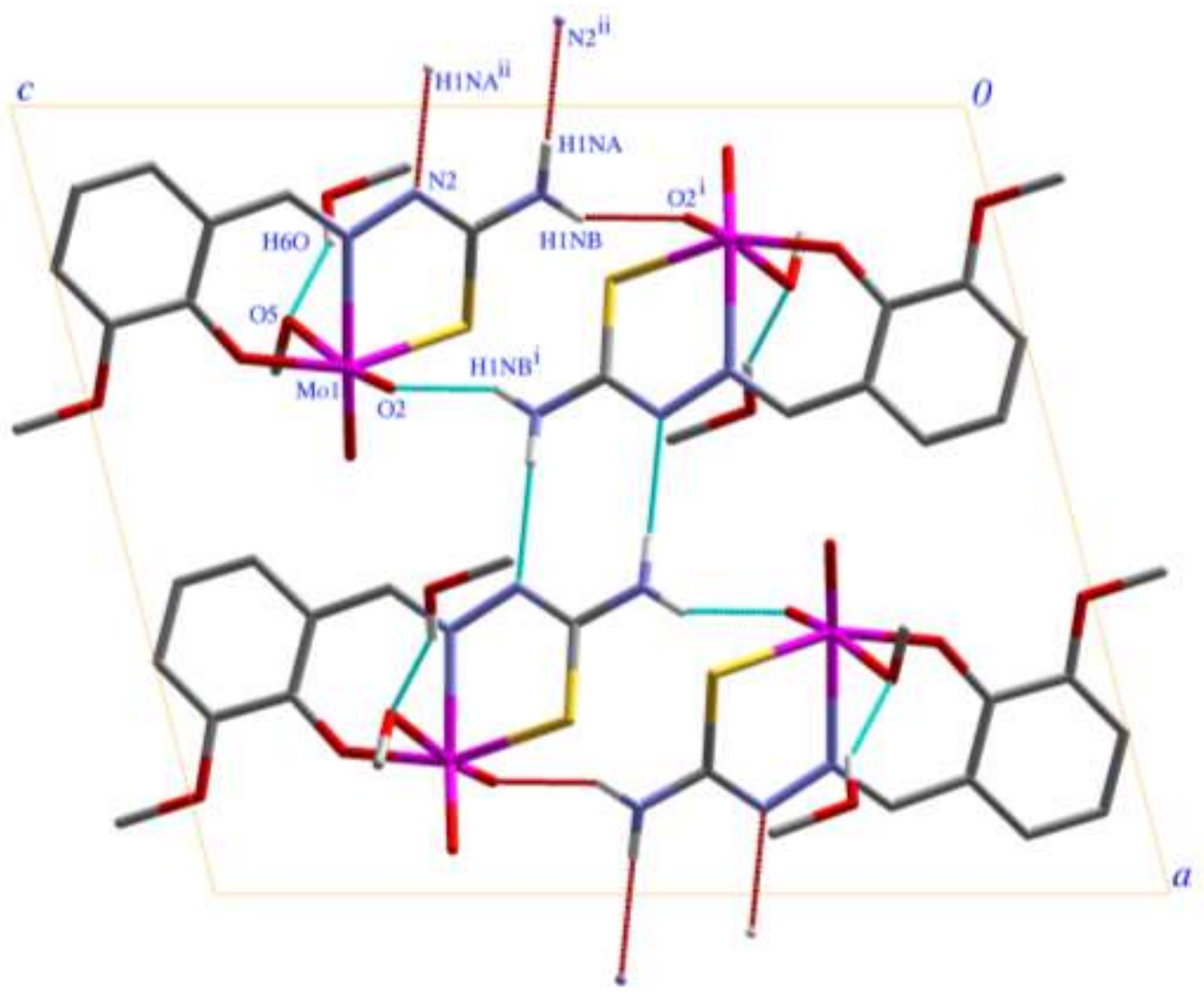

Figure 4. 


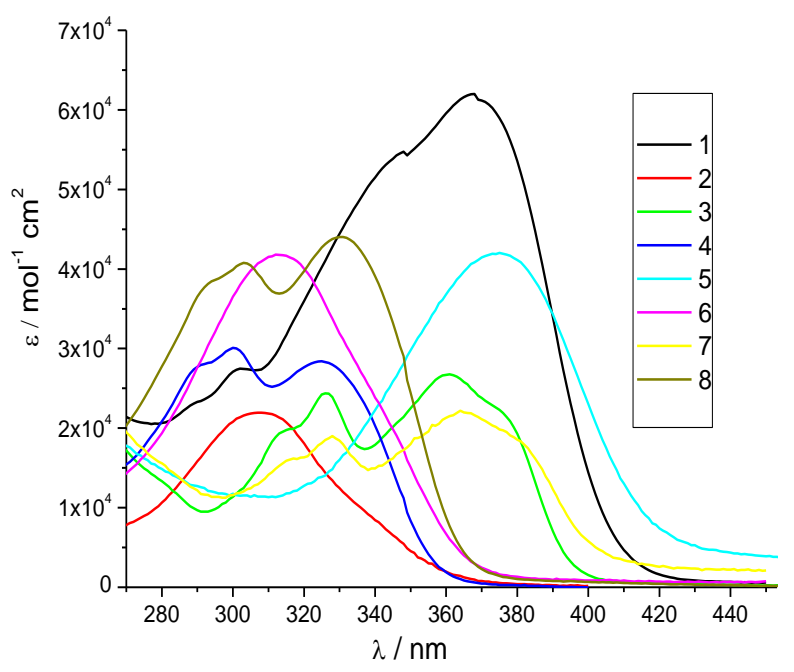

Figure 5.

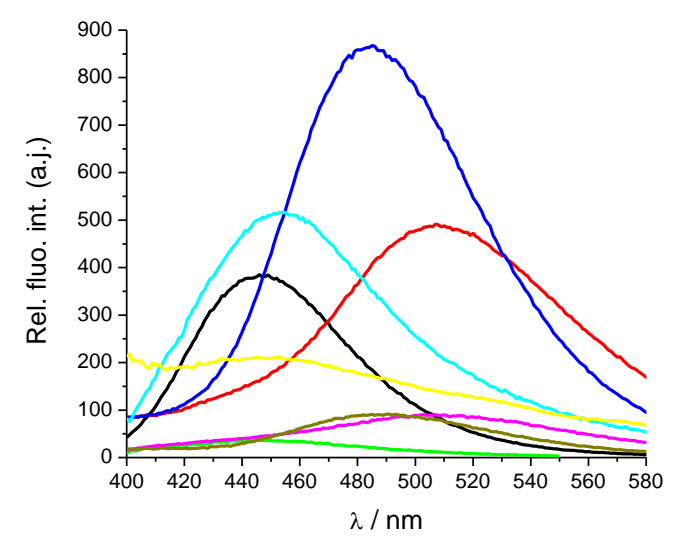

molybdenum(VI) complexes 1-8

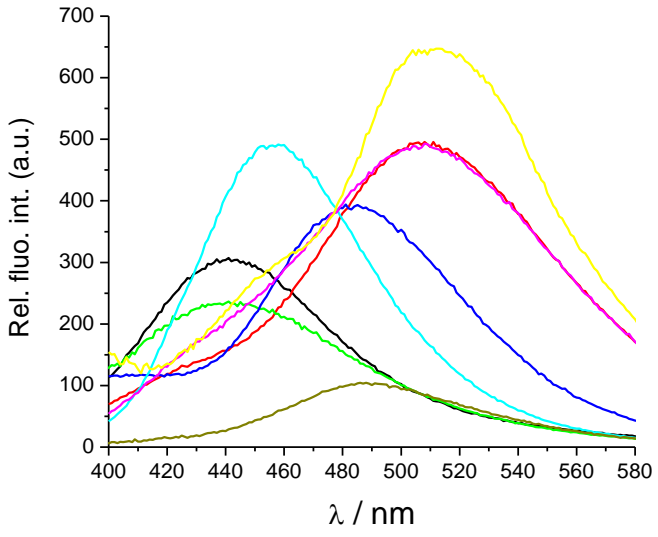

$H_{2} L^{1}-H_{2} L^{8}$

Figure 6. 


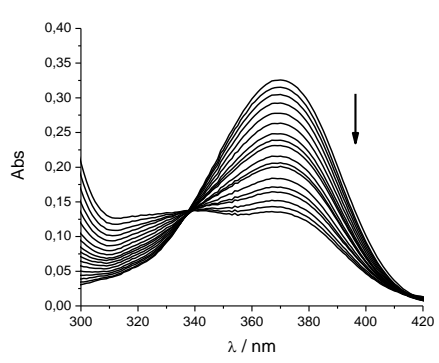

A

Figure 7.

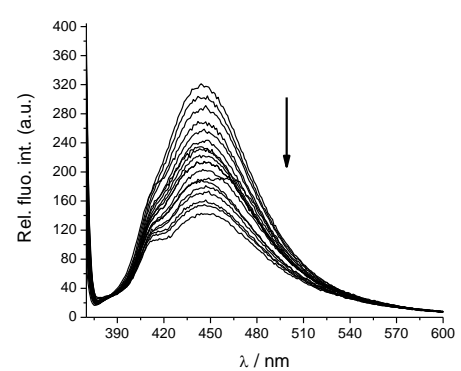

A

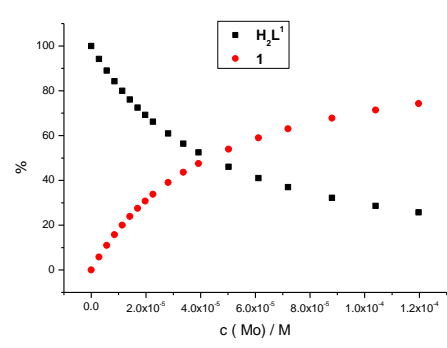

B

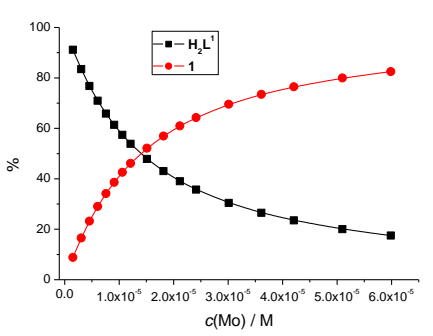

B

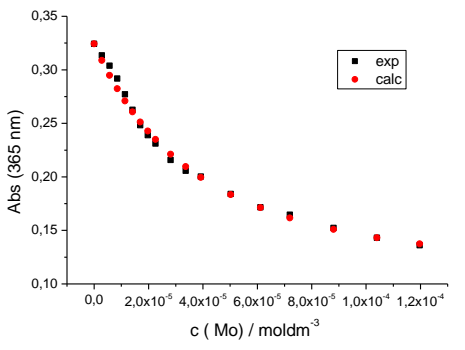

C

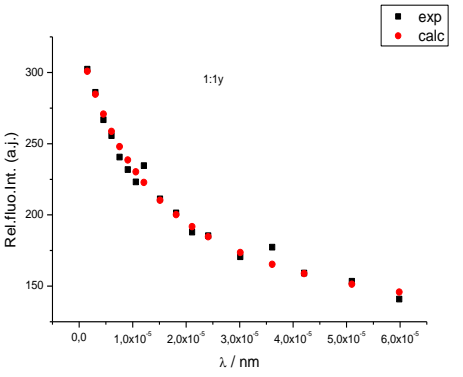

C

Figure 8. 